\title{
The Empires of a Composite Monarchy, 1521-1598: Problem or Solution?
}

The purpose of this chapter is to explain how the Iberian kingdoms' involvement in a complex and global composite monarchy affected the structural social tensions within the elites studied in Chap. 1. It will also discuss to what extent the resolution of the internal conflicts within the different kingdoms, and particularly within Castile and Portugal, led to a centralized military fiscal state, as is usually thought to have happened. It is, therefore, necessary to consider not only the fiscal apparatus but also the whole system for resource mobilization, thus challenging the vision that places emphasis only on taxes. In other words, we need to follow the arguments of J. Schumpeter, according to which tax systems (and by extension the mobilization of resources for war) are in fact a subproduct of social structures.

This line of thought leads us to reject the old stereotype of a society dominated by obedience to the king but also to question the model (popular in the 1980s) that emphasizes the high number and intensity of clashes between the monarchy and the Cortes, the cities, the aristocracy, and even the Church. ${ }^{1}$

${ }^{1}$ See part of this literature in Fernández Albaladejo (1992) and Owens (1980) for Castile. For the Aragonese territories, Colás y Salas (1982), Solano (2001), and Gil (1988).

(C) The Author(s) 2019

B. Yun-Casalilla, Iberian World Empires and the Globalization of Europe 1415-1668, Palgrave Studies in Comparative Global History, https://doi.org/10.1007/978-981-13-0833-8_4 


\section{Why CAstile?}

\section{The Problems of a European Composite Monarchy}

Charles V (1500-1558) inherited a collection of very different territories dotted across Central and Western Europe. ${ }^{2}$ His patrimony was probably the most extensive European political enterprise ruled in Europe by one person since the Romans. When the sprawling American territories and Portugal and its empire were added to this inheritance (in 1580), it became the most far-reaching territorial amalgamation known to history. The division of the Habsburg dominions between the two branches of the House in 1556, with the split of the Austrian (Ferdinand and his successors) and Spanish lines (Philip and his heirs), had not significantly diminished the dimensions of this dynastic conglomeration and the problems that ruling it entailed (Bérenger 1990).

This 'collection of kingdoms' created a 'problem without precedent' as far as it involved conflicts between logics derived from very different political agendas (Koenigsberger 1971, p. 4). Charles V understood that God had placed such vast terrains in the hands of his family 'for the good and universal peace of Christendom's and, it might be added, for the advancement of the House of Habsburg. But in each one of his territories, there were political projects framed according to its own internal interests and which did not fit in the Emperor's plan. It is understandable that he attempted to move according to 'the line of least resistance' (Koenigsberger 1971). But it was, however, inevitable that, given the dispersion of his states, their status as frontier regions scattered across Europe, and the multiple forms of power expressed in them, they would be the main reason for the 'mounting tension' that marked the history of the continent from the sixteenth century onwards (Rabb 1975).

First the Italian Wars against the French Valois; then the religious conflicts against the German princes, with the rebellion of the Netherlands

\footnotetext{
${ }^{2}$ To be more precise, this composite monarchy included the Low Countries, the FrancheComté, Tyrol, Austria and the states of today's southern Germany, Castile (and its conquered territories in America), Navarre, Aragon and the Italian states (Naples, Sicily, and Sardinia), the presidios or coastal forts of North Africa, and, later, the state of Milan. Bohemia and Hungary, inherited by his bother Ferdinand, were also associated directly or indirectly.

${ }^{3}$ This is the way Charles V expressed the idea in the Cortes of Castile. Patronato Real, 70-19, AGS.
} 
from the 1560s; and finally the campaigns against England, exponentially increased the demands and costs of conflict and transformed the character of war and the means of waging it in Europe. But, more important, the military tensions in which Charles V and Philip II were involved coincided with the apogee of another global polity: the Ottoman Empire. After taking Constantinople in 1453, the Turks had advanced into the western Mediterranean and the Balkans; to the East, they had moved into the Red Sea and as far as the Persian Gulf and the Indian Ocean (Casale 2010). In parallel, they took the North Africa thus building up 'a vast tri-continental empire' (Darwin 2008, p. 73). Based on reconciliation between Islamic traditions and dynastic absolutism, as well as on equilibrium between regional powers and centralization, the Ottoman Empire became the main enemy for Christendom and a problem for the economic contacts with Asia and within the Mediterranean. It was a power, therefore, which the Habsburgs simply could not ignore and one of the main reasons for warfare in Europe and religious rearming in the Mediterranean. This was even more so as long as the sultans were able to form temporary alliances with the French Valois (Braudel 1976, vol. 2).

The challenges facing the European states, and the Iberian monarchies in particular, must be understood in this context. On the one side, the 'military revolution', even if it remains a debatable concept, obliged them to instigate profound changes in the extant political and fiscal architecture (Parker 1995), which also affected the internal distribution of power. It also implied-it is said-what Joseph Schumpeter called the transition from the 'domain state' to the 'tax state': that is, to a state based not only upon the resources of the prince but also the greater commitment of the different kingdoms to tax payments. ${ }^{4}$ However-and this is often forgotten by economic historians - this shift had to be achieved in the context of a fiscal theory that was based upon four pillars, all of which had been manifested in the comuneros revolt: that the king should pursue his dynastic and personal policies with his own means (what the English referred to in the formula 'to live off his own'); that he could not collect taxes without the consent of his subjects; that fiscal contributions should only be spent to benefit the kingdoms that approved them, and not others; and that the royal patrimony could not be alienated without the kingdom's permission (Gilbert 1972, pp. 101-10).

\footnotetext{
${ }^{4}$ Schumpeter (1991). The ideas of J. Schumpeter have here a heuristic value rather than a historical one. But their explicative potential is important (Yun 2012).
} 
All these principles, on their own a problem for the rulers, interlinked with some technical difficulties, the most important being the need for credit to finance war or, in other words, the need to get loans situated upon future income. Furthermore, borrowing large sums of money on short-term repayment schemes involved punitively high rates of interest or non-monetary compensations in the form of privileges. The solution to this situation lay in obtaining a stable and predictable source of income, one that permitted the consolidation of short-term loans in longer-term repayment schemes at lower interest rates. But, in addition to this consolidation of loans and since most of them were used to pay for faraway campaigns, it was also crucial to be able to transfer funds across borders, which on many occasions entailed contravening the states' fiscal constitutions.

The Habsburgs were not, of course, the only dynasty to experience credit problems. As we shall see, similar troubles beset the rulers of France, England, and many other polities. But for the Habsburgs, these difficulties were a case apart. The dispersion of their domains and the Habsburg's geopolitical strategy led them to require more money than any other ruler. They had to negotiate with a large number of distinct assemblies, all of them of very different ilk; finally, not only did they need stable and reliable incomes, but it was also essential to arrange and, if possible, justify the transfer of funds between distant polities whose interests were difficult to coordinate. ${ }^{5}$

Contrary to what has often been thought, the process by which Castile became the fiscal and military backbone of the empire was not linear. It is also doubtful that everything depended upon the availability of men and a population easily recruited for war. ${ }^{6}$ Moreover, around 1520 Flanders and the southern German territories offered potentially greater financial resources than did Castile. In these regions, advanced financial systems had emerged thanks to market-oriented economies, which enabled them to provide the state military and fiscal resources. ${ }^{7}$

${ }^{5}$ This was recognized by contemporary observers, such as the traveller M. Suriano, 'Relación de España. Hecha al regreso de su embajada cerca de Felipe II en 1559', in García Mercadal (1999, vol. II, p. 305).

${ }^{6}$ As is well known, most of the soldiers fighting in Europe were not Spanish but Swedish, German, Flemish, and so on (Hale 1985).

${ }^{7}$ According to Tilly, this was important for state formation in the early modern period (Tilly 1990). 
The states of Burgundy and Flanders, tied to the imperial territories of Germany by strong economic bonds, had emerged at a very early stage as the pillars of Charles V's power. Here a dense web of patronage was extended, bringing enormous social, political, and even economic advantages to the Burgundian and Flemish nobles. Antwerp's commercial and financial development during the first half of the sixteenth century was one of the bases for the collection of funds (Braudel 1996, pp. 270-1). The connection between Flemish banks and German banking houses would allow the Emperor to make use of the services of families such as the Fugger and the Welser, who were also tied to him by their interest in exploiting mines (Carande 1987, vol. III, pp. 33-5). This axis, however, suffered a number of fiscal deficiencies. Like his uncle the Emperor Maximilian-who liked to laugh at the French and their fiscal subjugation by their king-Charles $\mathrm{V}$ had to base his finances in these states on incomes derived from renting out mines, which were used both as guarantees and to consign payments (Ehrenberg 1955, pp. 31-42). The proposals of the Estates General of the Low Countries always had to be discussed and approved by the provincial estates, and their final vote required unanimity, meaning that opposition from any one of a number of parties could become an obstacle to the Emperor's ambitions (Koenigsberger 1971, pp. 27-33; Tracy 1985, pp. 29-69). Furthermore, in all of these territories, the local assemblies were charged with collecting the monies they had voted through a convention that ensured that they kept part of these taxes.

Conditions were even more complex in the Mediterranean theatre. In Aragon, Catalonia, and Valencia, the contributions depended above all on the voting of extraordinary subsidies for specified purposes or campaigns and were very much controlled by the Diputaciones and Generalidades (see Chap. 1). It was, therefore, very difficult to use revenues secured in this way for operations that might involve the transfer of funds from one state to another (Tomás y Valiente 1982, pp. 41-50). In Navarre a number of additional problems emerged. The proximity of France, the almost continual conflict experienced after 1524, and the affection felt by a sector of the nobility for the Valois cause created conditions that made the Crown's appeal for contributions even more problematic.

In Sicily and Naples, similar circumstances prevailed. In spite of attempts to introduce reforms, marked limitations on the availability of funds existed (Muto 1980, pp. 28-35; Calabria 1991, pp. 42-5). A large chunk of the contributions were based on the system of donativos, basically forced loans that also had a negotiated element. These contributions were seldom 
extended for more than three years and therefore relatively unstable; moreover, they were always made in return for important concessions by the Crown. Furthermore, both kingdoms - and Sicily above all-lived under the continual threat of Turkish attack, thus making them very vulnerable while also obliging the Crown not to burden them excessively in order to preserve their political loyalty and stability. ${ }^{8}$

The situation in Castile was not noticeably better. Although often forgotten, there in fact existed very large fiscal demarcations (Yun 2004). Moreover, a degree of confusion reigned over rents, on where and how they were collected and from whom, above all when the seigniorial estates and royal demesne were concerned. Duties such as the crusade service (cruzada) easily ran into problems and local resistance. Further complicating matters, these taxes had to be negotiated with the Pope, which created a certain instability. The resulting irregularities created disputes between the different social orders and were exacerbated by abuses in revenue collection. On Charles V's arrival, some revenues were encabezados (granted by the cities at a fixed amount in exchange for the right to collect them), but many others were not, leading to problems in execution. ${ }^{9}$ This situation created a swarm of collectors, taxmen, and treasurers, few of them averse to lining their own pockets, while the local authorities often also retained a healthy share for themselves (Carretero 2000). These problems were aggravated by a great number and forms of overlapping jurisdictions. Moreover the monarchy's organization, based upon Consejos (Councils) with two crucial, but sometimes clashing, duties - the oversight of the king's authority and upholding the laws and customs of the many kingdoms over which he ruled-further limited the Crown's effective executive power (Fernández Albaladejo 1992).

Castile, we have seen, was a relatively rich kingdom, with a developing economy. But even in 1520-1530, its economy was very different from the more market-oriented economies of Flanders or Italy. Moreover, after the expulsion of the Jews, Castile clearly lacked great financiers capable of arranging the transfer of large funds from one dominion to another. Those groups who would later be capable of doing this had not yet reached a sufficient level of organizational maturity. And the Indies were not yet able to provide the funds necessary to establish and maintain the king's credit.

\footnotetext{
${ }^{8}$ According to Koenigsberger, the island was the 'most lightly-taxed of the kingdoms of the emperor' (1971, pp. 47-9).

${ }^{9}$ See, for more details based on primary sources, Yun (2004, pp. 261-3).
} 
As the comuneros' conflict had made clear, Castile was no less insistent than Christendom's other kingdoms that its resources should not be used for nondomestic causes or distant foreign wars waged in the defence of Habsburg interests (Perez 1976, pp. 546-7, 550-4). Pointedly, the comuneros had reminded Charles $\mathrm{V}$ that 'the monarch cannot use at his will the possessions of the crown that do not belong to him as his private property'. Furthermore, very much in tune with medieval theory (Chap. 1), the comuneros had reminded Charles $\mathrm{V}$ that it was his duty to ensure that 'all that is alienated from the royal crown should be returned to it'. ${ }^{10}$

These arguments did not disappear in 1521; rather they survived at a subaltern level and certainly complicated the mutual understanding between king and kingdom (Carande 1987, vol. II, pp. 49-50). Indeed, a number of old problems linked to the alienation of the royal patrimony returned to the spotlight. In its meetings of 1523, 1524, and 1528, the Cortes complained about royal taxes that had been illicitly alienated to (or by) the nobility; they also railed against what they considered the fiscal disadvantages of the royal demesne in regard to private seigniorial estates. As we shall see, these petitions for redress would not be entirely ignored.

Aristocratic discontent must also be considered. Having been the great ally of the Crown against the comuneros, the aristocrats found that their financial difficulties could not be properly addressed simply by a distribution of the booty captured from the rebels. The situation was very fluid. In 1524 Charles $\mathrm{V}$, pressured by the great estate holders on one side and the cities on the other, revalidated the 1504 legislation about the reversion of alienated incomes to the Crown. This measure was not likely to improve relations between nobility and king. The Church also failed to provide a network for the secure, reliable, and efficient collection of hefty funds. True, these years witnessed the establishment of the Council of the Crusade (Consejo de Cruzada), in part in response to the demands of the campaigns in North Africa. But the King of Castile had not only to negotiate the payment of sums with the Pope but also the precise figures to be collected from each diocese, monastery, and abbey (Perrone 1998). For all these drawbacks, the ecclesiastical services did in fact become an important financial resource, even being included in a number of asientos. But these services were neither reliable or predictable nor easily collected.

${ }^{10}$ See Patronato Real, 4, 84. AGS. and Perez (1976, pp. 548, 549, n. 129). 
Castile was not compliant or docile; nor was it particularly enthusiastic about Habsburg strategy. It was not the great panacea to the king's problems in 1517, or even in 1521, in the wake of Villalar. In short, contrary to an old view that only underlines a relation of obedience and agreement between kingdom and king, the monarch's margin for manoeuvre was quite limited.

\section{Castile, a Nervus Belli}

And yet, despite all of these factors, Castile became the backbone of the Habsburg empire for many decades.

A precise reconstruction of what the Habsburgs secured from their respective territories is very difficult. The rulers themselves would have been hard-pressed to present a clear idea of these contributions-an indication of the enormous difficulties that the dynasty had to face (Comín and Yun 2012). This having been said, the facts and figures that can be reconstructed speak for themselves. By the 1530s Castile was providing some $70 \%$ of the Habsburgs' resources in Western Europe (Comín and Yun 2012). Naples and the Duchy of Milan were the next most important contributors (Table 4.1). Even allowing for a healthy margin of error, these figures demonstrate the enormous burden that fell on these kingdoms. When they are viewed in the long term, the conclusions are no less striking. In real terms the incomes collected from Castile multiplied by more than a factor of ten between 1500 and $1600 .{ }^{11}$ This rise had been much quicker than in the other polities for which figures are available, such as England, France, or Holland (although calculations here are a matter of complexity the outcome can be easily accepted as an order of magnitude. See Graph 4.1). This growth was rapid until the 1560s, when the treasures arriving from America first came to make their presence felt. But they continued throughout the reign of Philip II, thanks to the increasing fiscal pressure and the second cycle of receipts of American silver brought about by the improvements in amalgamation techniques. This period also witnessed a more rapid increase in the contributions of other kingdoms, such as Navarre, Catalonia, and Naples, although everything indicates that the share of the royal income provided by Castile continued to be higher. In comparison with Naples, for example, the proportion

${ }^{11}$ See Comín and Yun (2012, p. 237, Table 10.2). 
Table 4.1 Charles V's incomes in different territories of the Habsburg composite monarchy

\begin{tabular}{lrr}
\hline & \multicolumn{2}{c}{ (Data in grams of silver, circa 1535) } \\
\cline { 2 - 3 } & \multicolumn{1}{c}{ c. 1535} & \% of the total \\
\hline Iberian estates & & \\
Castile & $\mathbf{5 0 , 3 9 4 , 8 8 3}$ & 69.1 \\
Catalonia & $\mathbf{1 , 9 4 8 , 7 5 0}$ & 2.7 \\
Aragon & $\mathbf{3 9 7 , 2 3 6}$ & 0.5 \\
Valencia & $\mathbf{6 5 8 , 4 8 0}$ & 0.9 \\
Navarre & $\mathbf{6 7 2 , 8 1 9}$ & 0.9 \\
Total & $\mathbf{5 4 , 0 7 2 , 1 6 8}$ & 74.2 \\
Italian estates & & \\
Naples & $\mathbf{1 0 , 1 0 3 , 7 8 3}$ & 13.9 \\
Sicily & $\mathbf{1 , 7 4 7 , 2 6 6}$ & 2.4 \\
Milan & $\mathbf{6 , 9 9 4 , 1 2 1}$ & 9.6 \\
Total & $\mathbf{1 8 , 8 4 5 , 1 7 0}$ & 25.8 \\
Low Countries & $\mathbf{7 , 2 3 4 , 4 0 5}$ & 9.9 \\
Total & $\mathbf{7 2 , 9 1 7 , 3 3 8}$ & 100.0 \\
\hline
\end{tabular}

Sources: Comín and Yun (2012)

between Castile and the Italian kingdom had been something like 5:1 in the middle of the century; by the end of the century, it was around 3.5 to $1 .{ }^{12}$ This trend was important (see below), as it provided an indication of the tendency in the next century (Chap. 8); but it does not, fundamentally, challenge the idea that in the sixteenth century Castile (and the Indies) had become the sinews of war.

This pattern helps to explain the increase, still more difficult to measure, of debt (meaning asientos, short-term loans taken at high rates of interest, as well as borrowing consolidated as juros) (Yun 2004, p. 318, Graph 5.7). This rise was also noticeable during the time of the Emperor but continued to grow throughout the second half of the century, as A. Castillo showed a few decades ago (1963). In particular, it led to a considerable increase in the amount of consolidated debt.

This helps to explain the increase in the size of military forces and war spending, another variable that is notoriously difficult to pinpoint. In regard to Castile, we know that the 'ordinary' budget for defence passed

${ }^{12}$ Data from Thompson (1976, p. 288) and Calabria (1991, p. 134). 


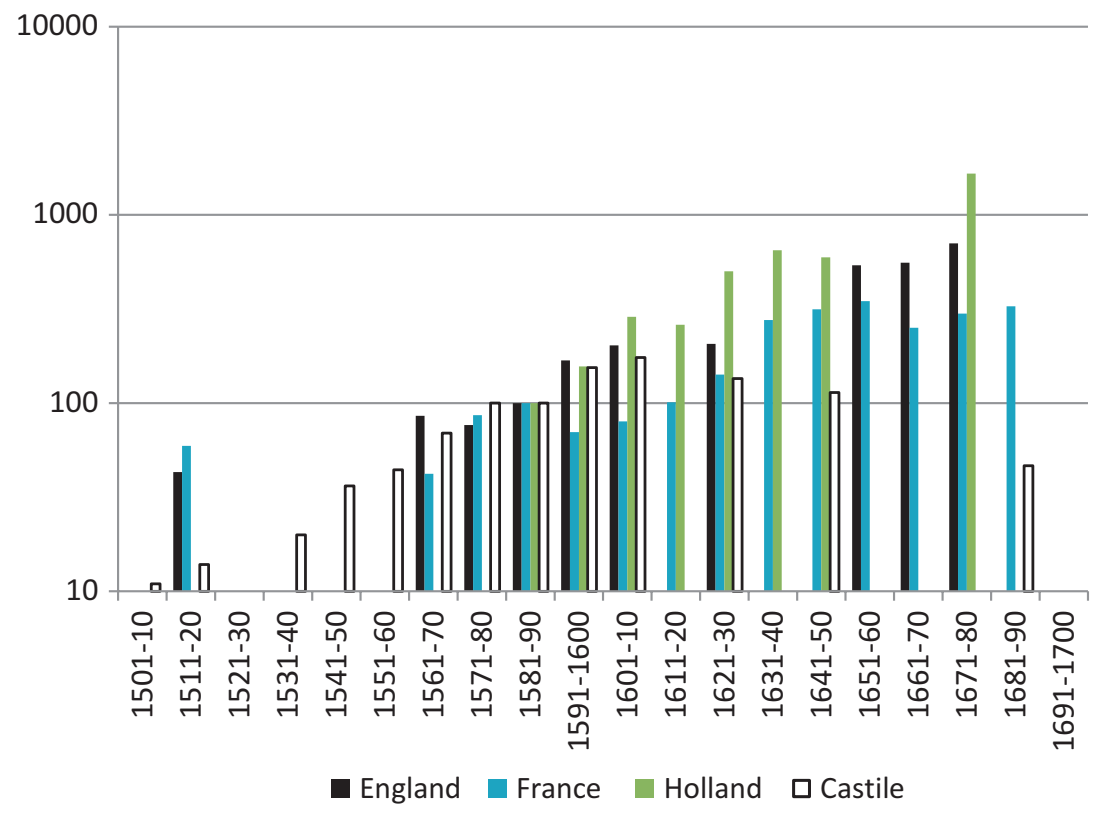

Graph 4.1 Crown's revenues in England, France, Holland, and Castile, 1500-1701 (current English pounds. Index: 1581-90 = 100)

Sources: My own elaboration from Comín and Yun (2012).

from some 740,000 ducats in 1559 to 3.4 million in 1598 . To this sum we should add the 3.45 million ducats assigned to pay for the war in Flanders (Thompson 1976, p. 288). This trend suggests a ninefold increase in costs, which is maybe exaggerated but which far outstrips any rise in prices. The military budget therefore increased in both real and nominal terms, even without taking spending in Flanders into account. Again, Castile paid the lion's share. More than $50 \%$ of its budget was spent on war; in contrast Naples spent something like $30 \%$ (six million against one million). ${ }^{13}$ The

${ }^{13}$ See Thompson (1976) and Calabria (1991). For Castile, only the budget for Flanders and defence is included here. Military costs in Naples increased from 1.3 to 3.5 and 3.3 million ducats between 1550,1574 , and 1600 . 
difficulties of these calculations notwithstanding, the Low Countries, Sicily, or Milan operated on a similar scale but with lower overall budgets (Parker 1972, pp. 139-57).

By the end of the century, the Habsburgs had established a system that transferred funds from one state to distant theatres of war. By this juncture a multitude of loans, including many raised in Flanders, had been set on the incomes of Castile, which was now financing campaigns in Portugal or the Azores, while other kingdoms, such as Naples, were paying for troops deployed on the Iberian Peninsula itself (Rodríguez-Salgado 1992, pp. 85-116). This development did not mean that the Castilians had forgotten their basic constitutional principles, of which they continued to remind the king whenever they could. ${ }^{14}$ These same practices were also evident in Naples and Milan (Calabria 1991, p. 55). Indeed, sometimes the Castilian assembly could see the value of financing a frontier conflict that did not affect Castile directly. Thus, during the War of Navarre against France and the conquest of Fuenterrabía, the Cortes and public opinion were entirely convinced by strategic concerns (Navarre was seen as the gateway to Castile) and the need to defend the Pyrenees frontier. ${ }^{15}$ On other occasions arguments of a religious kind were used, although these were often clumsy or forced. ${ }^{16}$ And there was no shortage of reasons why it was necessary to offer a hand to Hungary or to arm the fleet of Genoa. ${ }^{17}$

\footnotetext{
${ }^{14}$ In its petitions to the Cortes of 1542 , Córdoba alluded to the 'war of our holy faith against infidels' as 'the office and exercise of kings' and the only justification for the collection of taxes raised for this purpose. Patronato Real, 69, 61 AGS. Fray Antonio de Guevara justified war only when it was undertaken for 'that which for us He wanted to offer his blood on the Cross' ('Aquel que por nosotros quiso su sangre en la Cruz ofrecer' (Relox de Principes, 1994 [1529], 757).

${ }^{15}$ In 1523, when the recovery of Fuenterrabía was being planned, Carlos alluded to the fact that the King of France had 'attempted to occupy its lands for the discord that there was in these kingdoms at that time'. Patronato Real, 70, 22. AGS.

${ }^{16}$ Even if it proved impossible to hide the true reasons for it, this served as the means for justifying the continuation of campaigns in Italy against Francis I: 'the need to provide for the good and universal peace of Christendom and the conservation of his imperial authority, of his kingdoms and estates'; all of which, our source concludes, 'is necessary for the service of God, His Majesty and Christendom'. Patronato Real, 70, 19. AGS.

${ }^{17}$ On 5 December 1526, the Emperor summoned the Cortes to ask for extraordinary taxes in order to help his brother; the argument was that the Turk 'wants to overcome and subject
} 
Similar lines of argument had first been deployed in 1544, when it was deemed necessary to provide an extraordinary tax (servicio) to counter the alliance between the Turk and the King of France. ${ }^{18}$ Castilian society found more than a grain of truth in the king's plea for assistance. Indeed, this argument was precisely why this particular appeal proved so effective. ${ }^{19}$

The monarchy's composite character and its collateral effects would also prove decisive. These mechanisms were linked to the development of powerful commercial and banking networks within this political complex, which created political ties between the monarchy and the bankers and facilitated the transfer of funds to distant theatres of arms. The first of these conduits to emerge belonged to the leading German families, such as the Fugger and the Welser; later the Genoese rose to prominence, although they had actually begun earlier. The Centurione, the Balbi, the Spinola, the Sauli, and others advanced funds in return for access to the economy of Castile and America and for asientos offering high rates of interest. ${ }^{20}$ These great houses acted in coalition and had acquired or established networks spanning across the old continent, something that allowed them to achieve more than even the increasingly powerful Castilian bankers: to transfer funds across Europe with a certain degree of alacrity and a high level of security, making use of letters of exchange linking the great fairs of Castile, Seville, Flanders, and Italy.

These families - this is important in order to avoid erroneous argumentswere closely tied to the Habsburg dynasty and to its monarchical imperial

the Christians' and what he did was 'a very great offense to God, Our Lord, and his holy Christian religion by taking and occupying the lands and estates of the Church and of the Christian princes'. The Emperor also reminded the deputies of his responsibility before God, who 'put us here to reign over the Earth and gave us this Empire and estate, with which we serve him'. He also appealed to 'these kingdoms of Spain' that 'were among the first to believe in the faith of Our Redeemer and Saviour Jesus Christ and baptised by the water of the Holy Spirit and are so zealous for our Holy Catholic Faith', Patronato Real, 69. 63. AGS. In regard to the armada of Genoa, he placed emphasis on its strategic importance, alluding to its 'proximity to Africa and Turks that live there and come [here] every day'. Patronato Real, 69, 74, AGS.

${ }^{18}$ Patronato Real, lib. XVIII, ff. $29 \mathrm{v}^{\circ}-37 \mathrm{r}^{\circ}$. AGS.

${ }^{19}$ In 1539 cities such as Jaen recognized the Emperor's 'enterprises in the defence of our holy Catholic faith and the good of these kingdoms' and thanked him for them. Patronato Real, 69. 80. AGS.

${ }^{20}$ See the variety of these relationships in the different case studies presented in Herrero et al. (2011). 
system through bonds that were not simply economic (Herrero et al. 2011). The Genoese links, for example, were founded on the political settlement arrived at in 1528: here the families that controlled power in the republic made a pact with the Emperor, who became the referee of the internal relationships between the old and the new nobles (nobili vecchi and the nobili nuovi) in order to guarantee the political status quo of the city as well as his alliances with it (Canosa 1998). Genoa thus remained an independent republic although, in reality, it existed as a satellite state of the Habsburg conglomerate thanks to a collaboration based on the interlinking of both political agreements and financial services. Furthermore, for the Genoese the alliance with the Habsburgs, renewed in 1575, was founded upon the possibility of obtaining political and social capital, in part through a long process of fusion with the Castilian nobility, a trend that would in turn shape the history of the kingdom, as we shall see (Canosa 1998). ${ }^{21}$ Genuine clientele networks formed among financiers who were capable of circulating political and economic capital between areas. This trait goes a long way towards explaining the effectiveness of these networks, as these were not simply families but rather coalitions of alberghi, densely configured and close-knit associations with a very strong political component (Grendi 1997). In other words, to study the financial relationships between the Crown and the Genoese asentistas purely in terms of interest rates and other economic variables is to simplify things and to adopt an erroneous rationale.

The establishment of this system for the transfer of resources can be explained as a sort "primitive" financial revolution beginning in the $1530 \mathrm{~s}$ and set down in the general agreement for the alcabalas. As we shall see, this financial revolution was, in reality, a process that would take shape in the second half of the sixteenth century in Holland but would reach its maximum expression in England after 1688 (Brewer 1990). In the first case, it would consist of a process in which representative assemblies would achieve control over the budget and, by extension, over state spending and the consignment and repayment of debt (Tracy 1985). It would allow 'the contracting of long-term loans and the development of a consolidated debt, guaranteed by the authorities'. The system served to offer guaran-

\footnotetext{
${ }^{21}$ Among the Genoese families that established strong links with the Castilian aristocracy, one could underline the Spínola, very tied to the dukes of Albuquerque (Rodríguez Villa $1905)$.
} 
tees to subscribers with a consequent fall in interest rates ('T Hart et al. 1997, pp. 18 and ss.). What happened in Castile was very different, but it at least shared some of these traits. The situation was not entirely new, as from before 1530 the services voted by the Cortes to the Crown were used as a guarantee to the asentistas, who obtained a monopoly over their exploitation. Indeed, loans were even taken out against the guaranty of the 'ordinary' services or those made by the ecclesiastical institutions. ${ }^{22}$ But the encabezamiento of 1538 represented a clear step forward. In that year, the king and the Cortes finally agreed that a fixed sum would be decided upon and set down for a long period of time. In exchange for these concessions, Charles V agreed that the collection of taxes was to be administered by the cities according to quotas shared out among them. Obviously, this accord was favourable to the cities and the kingdom in general (and has always been seen as such), as it conceded them a margin for manoeuvre, and the quantities to be levied would fall in real terms due to inflation. But this agreement-and this has often been forgotten - also meant that the king obtained a secure, reliable, and predictable source of income, allowing him to win the confidence of lenders and to consolidate his debts upon it. As a result, the monarch gained an unprecedented capacity to assume debts, thus permitting him to raise the situado, the quantities paid as interest on loans, to above 8000 million maravedís by the end of his reign. ${ }^{23}$

During the following decades - and above all during the reign of Philip II-the figures for the encabezamiento de alcabalas would form the basis for discussions between king and kingdom (for this reason they were closely monitored by the asentistas). It should be stressed that the Cortes of 1559,1563 , and 1575-1577, meeting in the aftermath of royal bankruptcies, presented moments when institutional breakdown was a genuine possibility. But the upward revision of figures on these occasions allowed the consolidation of debts and permitted the system to function once again. Even at the end of the century, when in the 1590s the millones system was established, the eventual solution followed similar lines: the cities assumed responsibility for the collection and administration of the tax through rates which they themselves created and set (Fortea 1990).

\footnotetext{
${ }^{22}$ The Cortes alluded to how the service of 1525 was requested to meet 'debts of very great quantities of gold'. See Patronato Real, 70, 19, AGS.

${ }^{23}$ These ideas were developed in detail in Yun (2004), but had previously been presented in $\operatorname{Yun}(1998,2000)$.
} 
The system could be implemented thanks also in part to the treasures coming to the king from America. These shipments allowed the Crown to take asientos, short-term loans, with the guaranty of the American silver and then, in a second step, to consolidate those loans as juros (long-term public debt) endorsed by the alcabalas and other incomes. This meant a crucial step forward in another (neglected) dimension: since the warranty for the asientos was the American treasure, which belonged to the king, this operation escaped the control of the Cortes and could be used for any purposes. But, the second step also implied that the incomes of the kingdom-the alcabalas endorsing the juros - were also used to finance campaigns that had little or nothing to do with the interest of the kingdom but rather originated in the king's personal agenda. Though the cause of continuous complaint, this system thus camouflaged a crucial problem that was both technical and constitutional.

These developments also allowed the Crown to proceed to reduce its levels of interest payment on juros, which were to become (and remained until 1700) one of the cheapest forms of public debt in Europe. At their emission, they were, in fact, cheaper than English and Dutch debts (at least until the middle of the seventeenth century) and they were at the same level as some of the more economical debts emitted by the solvent city-republics of Italy (see Graph 4.2) ${ }^{24}$ The south of Europe was in fact precocious in achieving a reduction of the nominal interest rates levied on consolidated debt without proceeding to a fully fledged financial revolution (Yun and Ramos 2012, pp. 20-5).

This (apparent) long-term efficiency has recently inspired some (highly) optimistic assessments from the macroeconomic perspective (Drelichman and Voth 2014). However, and even if we accept many of the nuances proposed by these studies (see also the same revisionist line in Comín and Yun 2012), the macroeconomic perspective and the principal figures of income, debt, and expenditure are not sufficient in themselves. Furthermore, this view does not capture all of the sharp edges, drawbacks, and catches which are crucial to any genuine understanding of what happened. In fact, even leaving aside for one moment the effects (nearly always negative) of fiscal extraction on the economy (although these are often exaggerated), there are many obscure tones and shades to our canvass. Thus Castilian

${ }^{24}$ On the juros' interest rates and its evolution, see Álvarez Nogal (2009). 


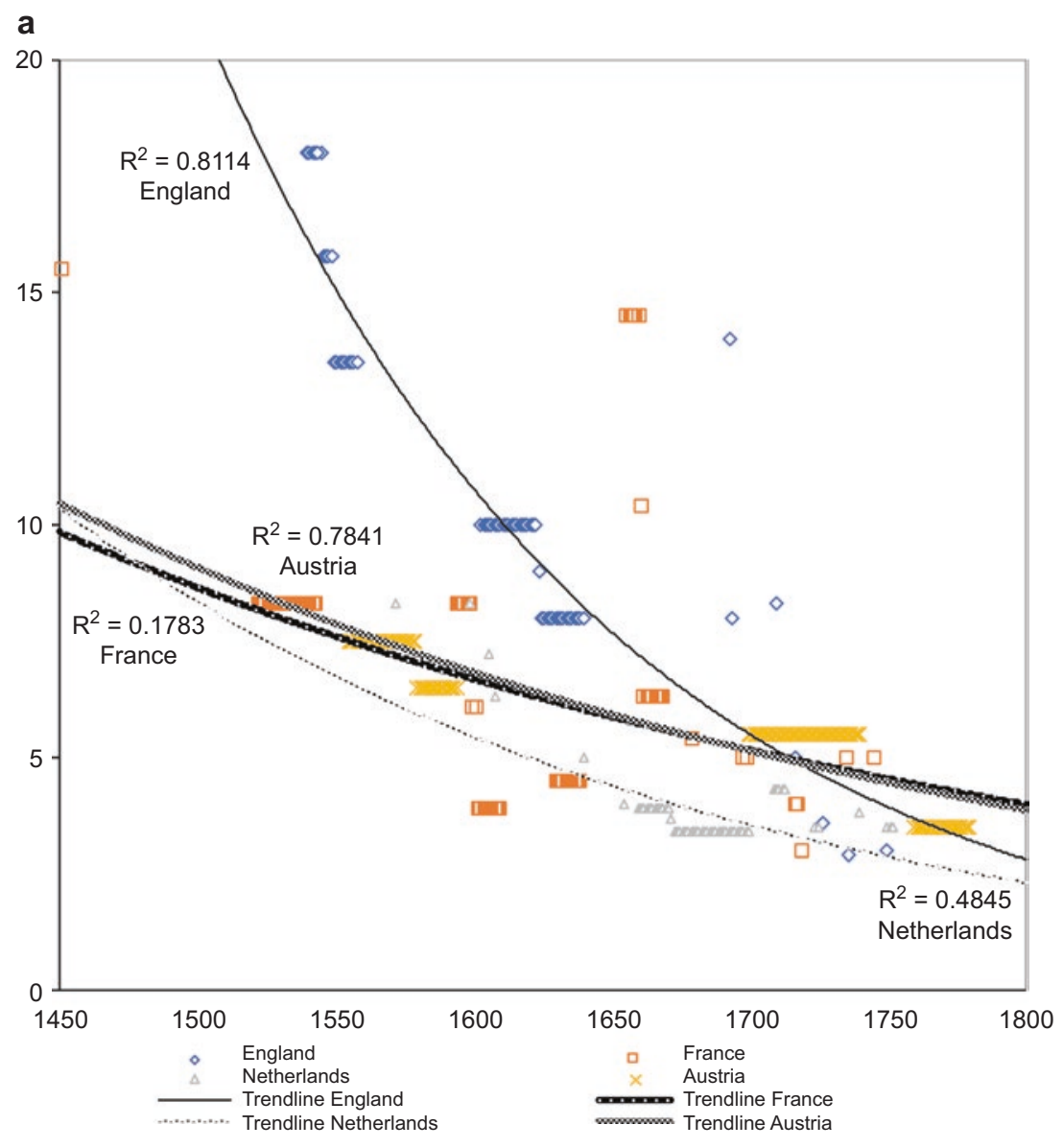

Graph 4.2 Interest rates of the public debts in Northern and Southern Europe, 1450-1800. (a) England, France, the Netherlands, and Austria. (b) Bologna, Florence, and Venice. (c) Milan, Naples, and Castile

Sources: My own elaboration from Epstein (2002, Table 2.1, nominal interest rates on public debt in Europe, c. 1270-1750) and Pezzolo (2012, Table 11.1, interest rates on government loans in Italy, 1450-1799). All trend lines correspond to an exponential adjustment. 


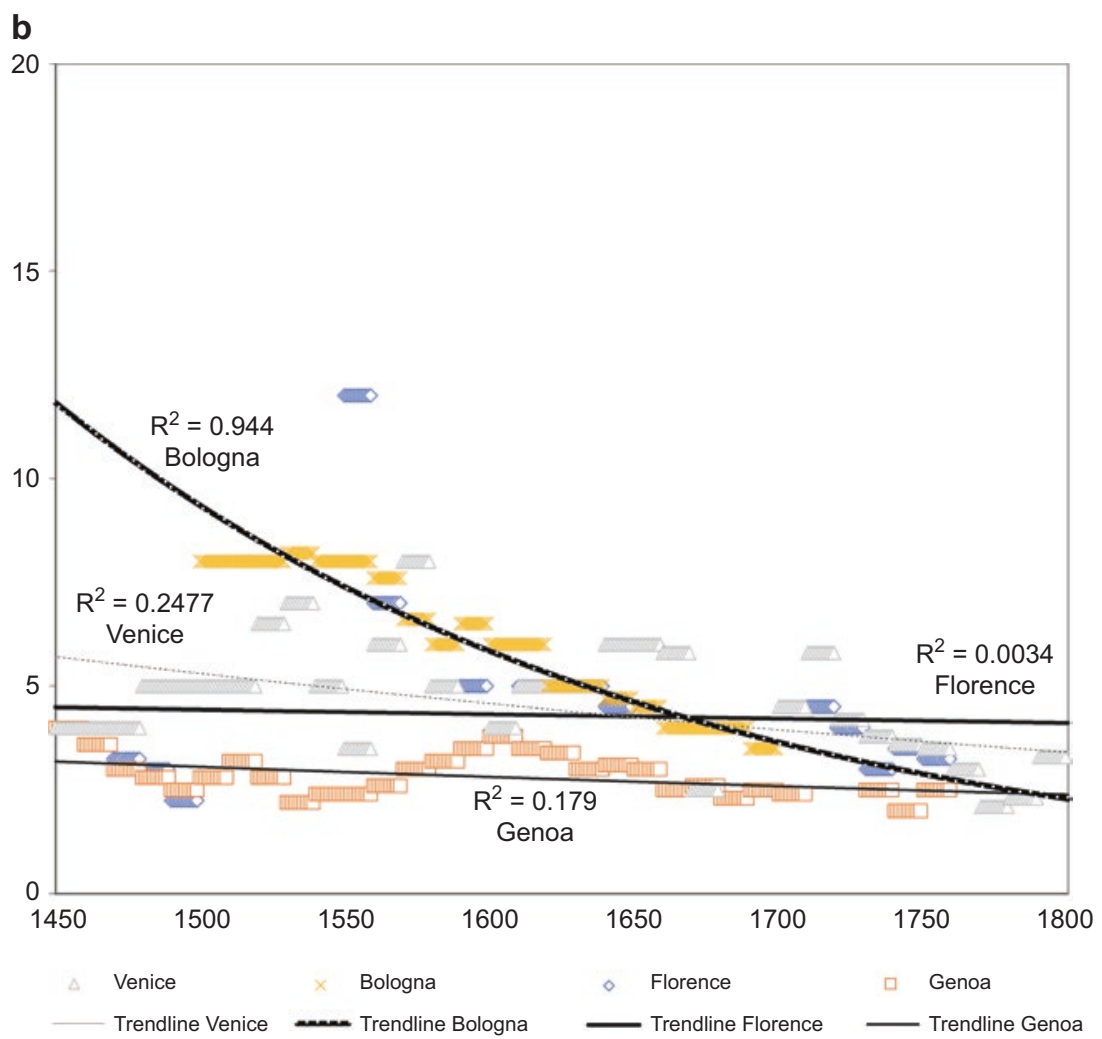

Graph 4.2 (continued)

debt increased more quickly than did incomes throughout much of the century - a factor leading to instability. Things were even worse in the short term, when war needs created genuine traumas for the functioning of the financial system. Moreover any study of debt and of the quantities involved in it is highly unlikely to paint a general picture of sustainability (needless to say, comparisons with today's ideas of sustainability are misleading. $)^{25}$ The frequent royal bankruptcies were the result of the

${ }^{25}$ Drelichman and Voth $(2014$, p. 33$)$ have even spoken of a relatively low volume of debt in respect to the GDP of Castile (not more than 60\%). Even beyond the weakness of their figures on GDP in terms of measuring sustainability, their estimate is difficult to accept 


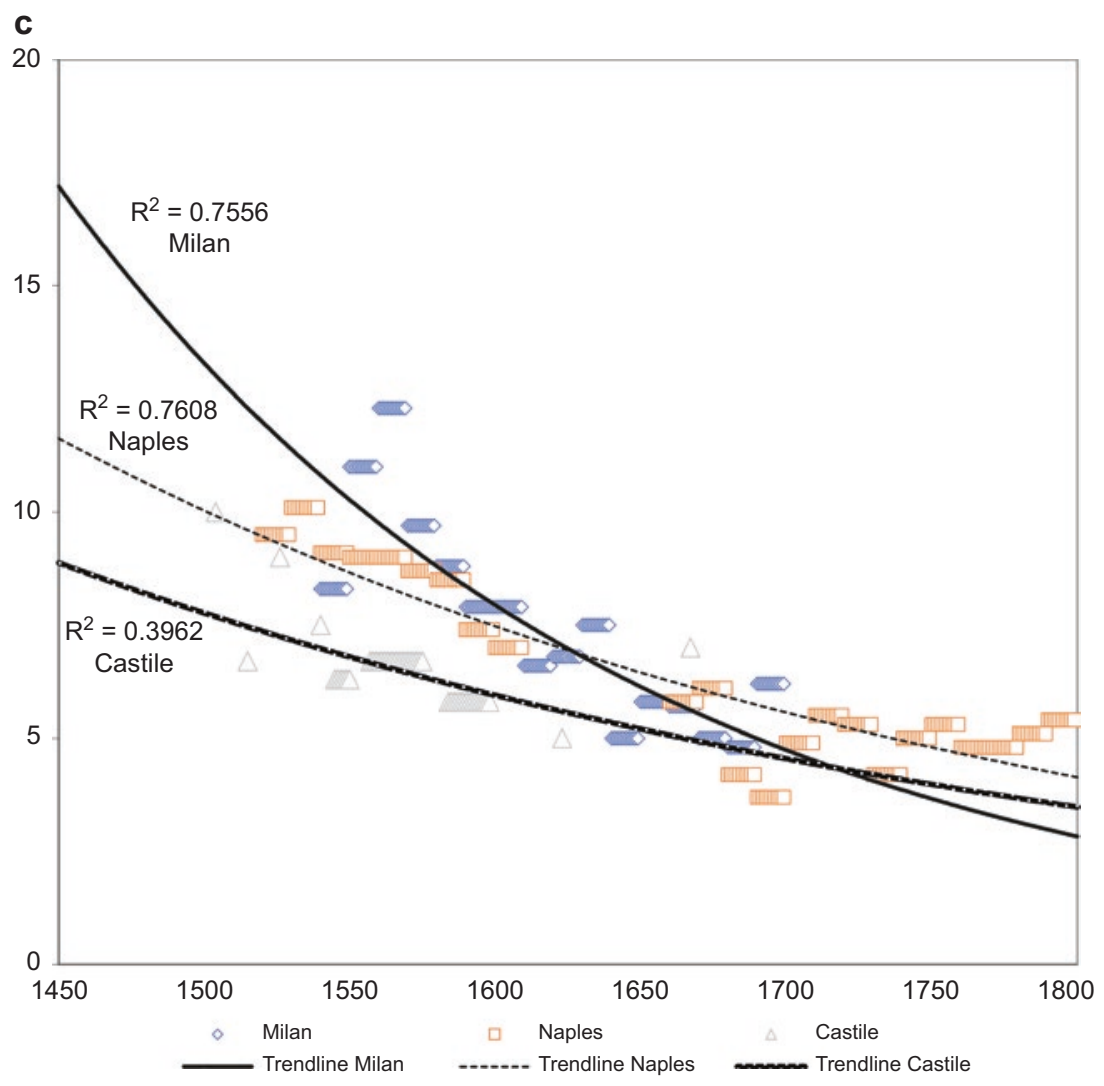

Graph 4.2 (continued)

periodical imbalance between debts and incomes. These were often accompanied by-sometimes heralded by - the recurrence to forced loans, the seizure of American treasure belonging to private individuals, or the Crown's delay of payments scheduled in the fairs of Castile.

(pp. 34-35, 116-25). The problem lies in estimating the total debt beyond the juros. This debt was, without doubt, small in relation to today's economies and had limited effects upon growth, to the extent that not all of the economy was monetarized. But taking into account the part of the economy that worked through monetary transactions, it has to be concluded that it had much more negative effects, in particular on the money market. 
It is true that the bankruptcies and the requisitions of American treasure were not the unmitigated catastrophe of legend, as they subsequently led to negotiations and agreements with the bankers and businessmen (the medios generales, in which both sides sought a compromise) (Sardone 2018). This should not surprise us. For a long time, historians have been aware of the negotiated character of the royal bankruptcies. ${ }^{26}$ But these manoeuvres and talks did not prevent moments of high risk for the financial and commercial economy in general and the relevant businessmen in particular, who were the most exposed and vulnerable within the financial system to violent jolts of this sort. ${ }^{27}$ It should be added that the entire system functioned through frequent negotiations with elites for ever-greater services to the Crown, as was the case, for instance, with the ecclesiastical institutions: these talks also created uncertainty. At heart - and in spite of the figures - the fiscal system of the kingdom was more or less efficient but also very weak. In the end this ship, whose sustainability had been sublimated, was re-floated-or, more precisely, the inevitable shipwreck was averted for another day-by burning a few more of its planks of wood. It survived, in other words, thanks to the constant alienation of the three elements-royal patrimony, state structures, and royal sovereignty-that it was supposed to sustain and protect (Chap. 1). The sale of alcabalas, tercias, jurisdictions, noble titles and offices, and unfarmed or common land belonging to rural communities became a slow, but unstoppable, drip feed over many decades, despite the complaints of the Cortes and the kingdom in general. And although a degree of legal subterfuge was introduced into most sales (it was commonly stated that the Crown could repurchase the rights or goods in question whenever it so desired), these clauses were never activated.

All in all, the fiscal system had been effective for the Crown but very demanding for the kingdom and the elites. But the whole picture cannot be understood if we do not consider it in a wider perspective which takes into account its social context, although this has often been ignored by recent studies on financial history. This will also help to situate finances in a broader scenario which is crucial for this book: the system of mobilizing resources in general and its implications for the political economy.

\footnotetext{
${ }^{26}$ See Lovett (1977) and Rodríguez-Salgado (1992).

${ }^{27}$ The fact (mentioned above) may have been important on account of its producing short-term alterations in the money market. This effect got worse from the 1550 s. According to Abed Al-Hussein's figures (1982, appendix 2, pp. 365-6), a greater quantity of delay in fair payments, and a longer period of payment, can be found as the century progresses, something which obviously provoked reasons for uncertainty.
} 


\section{A Conflictive Pact}

\section{The Challenges of a Dynamic Society}

From 1521 the cycles of great upheavals and civil wars that affected France, the German territories, or the Low Countries were absent from Castile. As we shall see, religious reasons in part explain this divergence (Chap. 6). Yet the social tensions derived from the dynamics within elites (Chap. 1) and from social and economic change were a day-to-day reality.

Documents detailing the popular political culture of the Castilian and Aragonese towns make it very clear that for many peasants the most important values were not necessarily those of obedience to the king. Ideas such as the 'zealous service of God and the republic of the poor' could come to be more crucial and might even collide with the demands for loyalty (Yun 2004). The conflict against the seignior, which burst forth during the revolts of the Comunidades and Germanias, was ever present in the Chancelleries of Castile throughout the sixteenth century and emerged not infrequently in Aragon (Kagan 1991). And this legal confrontation was just one facet of a sort of shadow boxing which sometimes even spilled out into actual violence and encompassed everything from collective disobedience to disputes over the use of agrarian resources.

All European societies of this period were characterized by a high degree of mobility (Vassberg 1996). But a case might be made for the Iberian states being above average in this regard, as regular and seasonal emigrations were extremely important for the peasant economies of the peninsula (Chap. 3). Another key factor, common to all European continental societies, was the multitude of jurisdictions. The result of mobility and the plurality of jurisdictions presented difficulties in maintaining social control. The inherent anonymity of a population working far from home or its place of origin created significant problems for the authorities, as did popular forms of socialization. Those who migrated from one place to another were often poor or vagabonds, who constituted a source of concern and conflict. The growth of the cities ensured that their internal social relations were increasingly tense and more difficult to control and order. Figures from picaresque literature such as Rinconete and Cortadillo or Lazarillo de Tormes reflected a reality that has shone through many historical studies.

But the internal tensions of this society were not limited to problems of this sort. The need for expansion felt by the lineages and the urban elites remained present during the sixteenth century. 
Many noble households found that their status maintenance costs grew more quickly than did their disposable incomes. This was especially true for those lineages whose revenues were badly adapted to the general increase in prices (Yun 2002a). The strengthening of the judicial system-above all in Castile - and the solidity of the rural community in many areas made it more expensive and difficult to revert to force and to the usurpation of lands and taxes as a means of expanding seigniorial rents at the expense of the royal patrimony (Kagan 1991; Owens 2005). The tension between spending and incomes was becoming increasingly marked. ${ }^{28}$ If in the fifteenth century the seigniors had had to build fortresses and equip and arm retinues, now they had even more reasons to spend money, military burdens aside. Matrimony had become a way of obviating and resolving conflicts and forming alliances between nobles: as a result 'the number of dowries shot through the roof' (Atienza and Simón 1989). ${ }^{29}$ The establishment of cadet branches was another significant expenditure. The expansion of the seigneurial domains to provide collateral branches with a property and so avoid interfamilial tensions also required investment and spending. Royal service, which was essential for the social promotion of both first- and second-born sons, constituted another significant form of spending. The Renaissance lifestyle entailed a need for ever-more expensive and luxurious palaces, thus pushing up the costs of social legitimization; similar programmes might also lead to altruistic spending on welfare, charitable institutions, and religious foundations. ${ }^{30}$ The result, in both Castile and Aragon, was an increase in nobles' debt from the 1520s, which threatened to dissolve both inherited patrimonies and 'free' possessions (those that were not entitled and therefore not subject to the mayorazgo) (Yun 1987; Abadía 1993, 1998).

The expansionist dynamic felt by the second-rank nobility and the urban oligarchies would be no less decisive than in the previous century and led to a policy designed to capture political and economic resources (Casey 1989, pp. 52 and ff.). The result was, once again, a fight for the amplification of patrimony or for the control of the key positions in the administrative and political systems, none of which could be acquired without expenditure. The growing prevalence of the mayorazgo increased

\footnotetext{
${ }^{28}$ See the case of Castile in Jago (1982) and Atienza (1987) and that of Valencia in Casey (1983). For more details from a general perspective, Yun (2004).

${ }^{29}$ See also the complains of the Almirante de Castilla in Diversos de Castilla, 37, n. 36, sf. AGS.

${ }^{30}$ Viñas (1970) and Checa (1988).
} 
these needs to the extent that, as for the high nobility, it required them to enlarge their patrimonies to compensate the lesser branches of the family in one way or another. The increasingly elitist nature of local government added pressure on rival factions to place their clients and creatures in the mayoral offices at a time when these institutions were gaining political relevance (Yun 2004). Although self-regulating mechanisms existed, these tensions were manifested in bitter factional and group conflicts over the control of municipal offices. ${ }^{31}$ A wave of banditry swept through many of the rural zones of Aragon, Catalonia, Valencia, and Navarre, often encouraged or sponsored by groups of local nobles. ${ }^{32}$

A further additional tension in the cities was the rise of businessmen who sought to gain access to the mayorazgos and town councils. Families such as the Dueñas and the Salamanca in Burgos, the Espinosa of Medina de Rioseco, and the Alcázar of Seville provided good examples of this sort. Bernabé Ortega represented this impulse in Medina del Campo. This trend was more destabilizing when it became mixed up in the religious problem. Spanish society decisively rejected crypto-Judaism, and any manifestation of it might be considered as evidence of tainted lineage. Together with the notion of purity of blood, this rejection created a model of conformity upon which the ideal of an imagined community was formed. These developments would convert these themes into a source of discord among the elites. An accusation of crypto-Judaism or impure bloodwhether true or not-might act as a corrosive poison that would end up affecting all members of an urban oligarchy and, in particular, their ability to reproduce their status through matrimony. That is to say, any such allegation would hit the key social capital that was crucial for the reproduction of the group. The case of the dispute between the Sotos and the Riquelmes in Murcia, explored in an excellent study by J. Contreras, demonstrates that quarrels of this kind were not simply evidence of social and religious discrimination against a minority. ${ }^{33}$ They were much more than this, producing enormous tensions in the very heart of the oligarchies and affecting the very consolidation of the dominant coalition.

\footnotetext{
${ }^{31}$ See, for example, the case of Murcia in Contreras (1992) and Ruiz Ibáñez (1995).

${ }^{32}$ Elliott (1963), Torres (1994, pp. 103-19), Reglá (1966), Vilar (1962), Colás y Salas (1982, pp. 159-81, 208-76).

${ }^{33}$ The studies on the subject are many. For the families cited as examples, see Yun (1987), Lohman (1968), Pike (1966, 1978), Abed Al-Hussein (1982), and Contreras (1992).
} 


\section{Absolutism As a Threat to the Dominant Coalition}

The development of absolutism would accentuate two forms of conflictthe first within the dominant elite and the second between its different social sectors and the king. ${ }^{34}$

As we have seen, the evolution of royal authority reduced the nobility's chances of recurring to violence or to the usurpation of lands. Its problems would have to be addressed with other solutions. During the first years of Charles V's reign, the Crown's policy of trying to reclaim alienated rents gained momentum. In 1524 measures that had been favourable to the aristocracy in Castile were revoked. Something similar happened in Navarre. Both Charles and his son repeatedly appealed to their nobility for military help, thus obliging them to meet additional military costs, at least in principle. The campaign against Tunis (1535), the repression of the Moriscos in Granada (1568-1571), the annexation of Portugal (1580), and even auxilium requests in specific instances compelled many nobles to mobilize troops and incur costs that threatened their economies. The advance and improvement in the organization of royal justice also posed a threat to the seigniorial jurisdictions. This was the case not only in Castile but also in Aragon, Valencia, and Catalonia, where seigniorial jurisdiction was even stronger but where a new generation of jurists and judges sought a balance of legal power that was more favourable to the king. Philip II even used the Inquisition in Aragon against the elites of the kingdom and, more generally, its laws and customs. He applied laws regarding the ownership of salt mines and undersoil wealth that went directly against the interests of the seigniors and in favour of those of the Crown.

The conflict between, on the one side, the urban oligarchies and the Cortes and, on the other, the king has assumed a crucial role in recent interpretations of this period. The increase in fiscal pressure was, without doubt, the most important-or most visible — cause of these tensions. Each round of negotiations over taxes was accompanied by a din of complaints and grievances. In Castile one of the worst moments came with the revision of the alcabalas in the 1560s and 1570s and actually resulted in armed conflicts in some cities (Jago 1981, 1985, 1989). Debates over the millones tax in the 1590s were equally fraught (Fortea 1990). Despite the manoeuvres to hide or justify it, the fact that some of these funds were used to pursue interests outside the kingdom further aggravated the situation.

\footnotetext{
${ }^{34}$ For what follows, see Yun (2004, Chaps. 5 and 6).
} 
The efforts by Philip II to make use of the Inquisition against his rebel secretary, Antonio Pérez, unleashed an open conflict between the Crown and the Justicia, a sort of chief magistrate, and the city of Zaragoza. ${ }^{35}$ Mention should also be made of the Catalan Cortes of 1585, which were especially difficult. Justified as a reform to end fraud and maladministration, a new tax (the fifth, el quinto) would further intensify the stand-off between the Catalan elites and the monarchy (Hernández 1996, passim).

The growing fiscal pressure on the Church and the continual demand for services provoked conflicts not only with Rome but also with the Assembly of the Clergy of Spain. Episodes such as the interruption of the ecclesiastical services (in 1519, 1533 and 1556) and the excommunication of Charles $\mathrm{V}$ by the assembly indicated an undeniable degree of tension (Perrone 1997). And the difficulties between Philip II and the clergy and, indeed, with Rome were even more keenly felt. The Crown's demands on the Church also increased during the second half of the century (Ulloa 1977). By this period some of the services demanded of the clergy had become so regular that, despite being subject to negotiations, they were used to endorse the asientos and even to consolidate juros (Ulloa 1977, p. 567). The increase in tax collection is all the more significant to the extent that by this time there emerged symptoms of a slowing down of the overall growth of Church income (Yun 2004). For this reason, the tensions between the ecclesiastical institutions and the Crown did not come to an end, above all during the negotiations over the subsidio. Furthermore, even if many of these concessions were justified by the need to defend Christendom, there remained a notable unwillingness to deploy the forces and funds of the kingdom in wars fought far from its borders or for the sole furtherance of dynastic interests. This was even the case when funds were collected by, or from, the clergy. ${ }^{36}$

${ }^{35}$ Colás and Salas (1982) and Gil (1988). A more detailed version of this conflict within the argument of this book, in Yun (2004, pp. 364-76).

${ }^{36}$ Already during the Comunidades, Augustinian and Dominicans friars in Salamancas complained that 'it is unreasonable that His Caesarian Majesty should spend the incomes of these kingdoms in the other lands that he has, as each one of them is enough for itself and this kingdom is not obliged to any of the others, nor subject [to them], nor conquered nor defended by foreign men', Estado, 16, 416, AGS. 


\section{A Crucial do ut des}

Conflict is, however, just one side of the story. The relationship between the Crown and the elites was in fact twofold. The other side of the coin was the pact between the elites and the Crown that facilitated the former's social consolidation and resilience, as well as the maintenance of mutually beneficial relationships.

For the Castilian aristocracy, many of the new measures, like the plans for the reversion of alcabalas to the Crown, ended in nothing more than the paper on which they were written. Moreover, the demands of the Crown gave rise to a new system for financing noble debts, one that allowed them to mortgage the incomes of the mayorazgo through censos. This was, in reality, a legal fiction as in theory possessions tied to the mayorazgo were inalienable and therefore could not be used as collateral for borrowing. The formula that came to be used, therefore, was that it was the rents generated by these possessions that served as payments and as a collateral for the capital taken out in censos. This allowed them to replace short-term borrowing taken out at high interest levels for long-term loans given on much more favourable terms (Yun 1987). This manoeuvre relaxed the pressure on debts and was similar to the effects obtained with asientos and juros by the Crown. In fact the rate of interest charged on censos was set as equal to that on juros.

The adoption of this system is highly indicative of underlying developments. In effect the king granted permits to use the censo to encourage the nobility to continue to play its part in the auxilium of the Crown (Yun 1987). This auxilium, moreover, quickly came to be understood in the broadest terms, including diplomatic service (habitually paid for by the diplomats themselves), their presence at court, and participation in royal tours. But, from the very beginning, these permits were granted to resolve the problems of the noble family, whose stability was understood to be important for the health of the kingdom. Thus, censos were used for a wide variety of purposes: to pay for dowries, to cement matrimonial agreements approved by the king, to finance the careers of second-born sons, to buy rents sold by the Crown and so expand the incomes and dominions of the lineage. All in all, these were uses that served the expansive dynamic of the seigniorial households and relaxed their inner tensions.

Of course, censos did not solve all of the nobility's debt problems, which continued to grow on account of being a substantial part of the logic of aristocratic economies. But things did not stop there. From the last decades 
of the century, the king, taking advantage of the growing circulation of money, proceeded to lower the interest rates on juros, which also affected the official interest rates levied on censos and allowed many noble families to reduce their borrowing costs (Yun 1987). When these debts led to unsustainable situations, they resulted in the seizure and management of the seigniorial estate by royal officials. Although these arrangements have been considered another absolutist attack on the nobility, they only lasted until the financial health of the mayorazgo was restored; furthermore, the seigniors retained full legal ownership of the estate and received a pension from its revenues throughout the period of royal management (Atienza 1987). The king's intervention in the señorios was the opposite: a crutch to allow them to keep walking. It is to be noted that, contrary to the arguments that view absolutism as a simple means for the reduction of the power of the nobles, all these measures were taken while invoking the plenitudo potestatis of the king and justifying the importance of the mayorazgos as institutions that preserved the correct order of the 'republic' (Yun 2004).

The auxilium was also a motive-when not the pretext-for the granting to the nobility of favours, grants, salaries, and assistance that raised their political and social capital as well as their incomes. Often these rewards came together. In 1600 the Count of Benavente obtained an annual salary of 60,000 ducats as viceroy of Naples, the equivalent of the revenues of his estates at this time. And to this we might add additional sources of income, not all of them easily located or entirely licit, as well as the political power which this office entailed. The king also took advantage of other instruments to help good relations with the nobles. The Military Orders were exploited as a means of patronage, with the concession of their encomiendas and military habits used to confer prestige, influence, and income (Yun 2004).

This do ut des was also clearly manifested in the overall relationship with the urban oligarchies. Despite the bitter negotiations over precise figures, both the system for the setting of alcabalas in Castile and the increase in ordinary services across the kingdoms framed obvious fiscal pacts between the Crown and local oligarchies. The fact that the alcabalas were maintained for long periods beneath the rate of inflation contributed to the calming of tempers. But, above all, even in the most tense moments, the rise in taxes was implemented while respecting and even increasing the autonomy of the cities that collected them, thus benefitting the oligarchies. The forms generally chosen for collection - the renting out of rights to persons close to the oligarchy or the division of taxes through branches of economic activity - gave a big power to local elites. Even the service of 
the millones in the 1590s, which provoked a wave of protest, was finally approved in Castile thanks to the cession to the cities of the rights to collect and manage this new duty (Fortea 1990).

The millones and other forms of taxation compelled the Crown to concede rights for the emission of city debts, which allowed the cities to make advance payments on the promised sums. Opportunities such as these were accompanied by permits for the creation of municipal taxes to pay these debts with the money collected (Ruiz Martín 1994). This facilitated the control of municipal properties by the loaners, who were none other than the members of the urban oligarchy itself and the powerful local ecclesiastical institutions (Yun 1990). Moreover, one of the results of this system was to justify debts that were taken advantage of by the cities and the local elites, who were able to buy offices from the king, acquire jurisdictions and privileges, take possession of unfarmed land, and so on. In this regard there were certain parallels with the profits taken by the nobility on the censos levied on mayorazgos. The result of all of this was, in the first place, a greater meshing and dependence of the destinies of the monarchy and those of the oligarchies. Another consequence was their enhanced capacity for renovation without this leading to great changes in their internal dynamic (Soria 2000).

Something similar happened in the Crowns of Aragon and Navarre, although some important points of divergence should be noted. As we have seen, here tensions coalesced into violent conflicts. ${ }^{37}$ But the eventual resolution of the crisis is in itself evidence of the intense relationships forming between the elites and the monarchy. It also underlines the role of these ties in facilitating the elites' social consolidation and extension.

In Aragon, as elsewhere, the political theory of the period reflected this union with the king. According to this ideology, the 'embodiment of the body politic as a whole' resided in the 'union of king and kingdom' or the 'king with Parliament' - this was a chamber very much dominated by the high nobility (and in this respect substantially different from its counterpart in Castile). ${ }^{38}$ In conformity with this representation, the collection of

\footnotetext{
${ }^{37}$ The literature on this theme is extensive. An overview, with some modifications of previous arguments, is provided in Yun (2004, Chap. 6).

${ }^{38}$ Though these expressions refer to the Crown of Aragon (Gil 1991, p. 80), the fact is even clearer in Castile (Fernández Albaladejo 1992). In Valencia 'un reciproco y mutuo contrato entre vuestra majestad y dicho reino' ('a mutual and reciprocal contract between Your Majesty and his kingdom') was also acknowledged (Casey 1983, p. 243).
} 
services voted in their respective Cortes fell to the Generalidades and Diputaciones, for their own benefit and that of the elites. ${ }^{39}$ The balance between the king and kingdom was also maintained thanks to the Audiencias and, above all, the survival of the Council of Aragon which, like the other councils, represented the laws and customs of the kingdom before the king himself. The very organization of judicial power itself, established in institutions such as the Justicia de Aragón which defended the rights and by-laws of the kingdom against royal aggrandizement, demonstrated the limits of the king's power and would end up producing an equilibrium. In the aftermath of the conflict of 1591, the king sought to make an example of Aragon and introduced reforms to both the Cortes and the Diputación. These measures meant that the monarch could now appoint the Justicia de Aragón and a 'foreign viceroy' (meaning a nonAragonese person). But, far from proceeding to suppress the privileges upon which the jurisdictions of seigniors and cities depended, a new equilibrium was sought between local powers and the monarchy. Therefore, despite the appointment of viceroys born outside the kingdom, this institution exercised an important role as an intermediary between local elites and the royal Court.

The nobility was not seriously prejudiced. In Aragon the king's permission was not as indispensable as it was for the management of censos taken out on mayorazgos in Castile. But the system, applied in a way that was not dissimilar to that of Castile, also allowed seigniorial economies to resist (Abadía 1993, 1998). In Aragon censos on their own benefit were generally set down by noble households on the incomes of the towns and villages within their seigniorial estates: the fact that the nobles exercised a high degree of control over these settlements was decisive in this regard. On the whole the Aragonese nobles were less involved in the 'enterprises' or campaigns of the Habsburgs than their Castilian counterparts: their rewards and remuneration were correspondingly smaller. But their involvement not only increased over time but also drew in a disproportional number of the greater houses, like the Requesens and the Gandía. Some of these families came to intertwine themselves to such a high degree with their Castilian counterparts that it becomes pointless to speak of any distinction or division between them. True, they maintained many rivalries over jurisdiction (indeed some disputes were even of a judicial nature), although these tended to be limited in scope.

\footnotetext{
${ }^{39}$ Gonzalez Antón (1989, pp. 664, 666) and García Cárcel (1989, p. 685 ).
} 
The elites of the most important cities, such as Zaragoza, Barcelona, Valencia, and Pamplona, found their situations moderately favoured and improved across a range of issues. The system for the collection of taxes was itself based upon the cities' marked autonomy, which reinforced the oligarchy's political capital. The growing emission of municipal debt, nearly all of which was purchased by the oligarchies, increased their political and economic power. These developments were reflected in the elites' increasing domination of the urban governments, a trend that in turn favoured understanding between the Crown and the oligarchies by creating channels for better communication (Amelang 1986, pp. 45-6; Furió 1995 , p. 256). Moreover, after the uprisings of 1580 , the urban elites of the kingdom of Aragon increasingly integrated themselves into the monarchy's judicial and bureaucratic apparatus (Gil 1988). The fact that this trend was much clearer in the ecclesiastical administration resulted in there being no effective structural division between the Church in Castile and Aragon. Individuals drawn from these elites moved seamlessly between the two realms: this, again, was an important factor.

In Castile, as in the territories of the Crown of Aragon, the sale of jurisdictions, noble titles, unfarmed lands, rents, and censos and juros set on municipal finances served to satisfy the needs for social promotion and consolidation of many members of these families (the sums involved were rather different across these kingdoms). The growth of the royal bureaucracy also created employment opportunities for them. The granting of military habits and the enrolment in royal armies, in whose regiments more and more Spaniards were active, had a similar effect (see the data given by Wright 1982). Another opportunity-the chance to seek office within the ranks of one of the most expansive churches in Europe-further eased the fortunes of the oligarchies, who provided many members of the ecclesiastical elites. ${ }^{40}$

The opportunities open to the oligarchies to take advantage of the growth of the ecclesiastical institutions were just one part of a broader process: despite the pressures exerted by the Crown, the Habsburgs were able to renew their pact with the Catholic Church and thus to provide it with an outlet for expansion as an institution of power with an economic character. The Catholic policies of the Habsburgs led to the growth of the number of institutions and offices, as did the stream of donations and

\footnotetext{
${ }^{40}$ We will return to this matter in the next chapter; see also the case of Córdoba in Soria (2000).
} 
endowments made by the faithful and the related rise in ecclesiastical revenues. America was essential to this process. It was a vast virgin territory into which the ecclesiastical economy rapidly expanded, with the religious orders (the Dominicans, Franciscans, Hieronymites) being particularly voracious colonizers from the first moments. But it was the Jesuits, active from the second half of the century and in whom the presence of the low nobility and the oligarchies was important from the very beginning, who expanded at an unprecedented rate. America was also crucial to the growth of the secular clergy and led to an intense relationship between it and the monarchy, one that reinforced the bonds of mutual interest. From 1508, when the Crown obtained the right to 'present' (in effect, to appoint) all ecclesiastical benefices from parishes to bishoprics, its control over the life of the Church was combined with a unique capacity for patronage. In 1543 the monarchy won the right to set episcopal jurisdictions, thus reinforcing and extending its powers in America. Between 1511 and 1564, it created 22 dioceses; appointments in them were controlled by the Council of Indies. Clergy even had to swear loyalty to the king. Ecclesiastical patronage over the Indies (the right to name bishops) was considered the 'richest stone, the most beautiful pearl, in the royal diadem'. Apart from wealth, this right gave the Crown the ability to create ecclesiastical clientele networks that were unparalleled in Christendom. It was a form of reaching a general deal with the clergy and the elites, from whose number the clerical elite was recruited (McAlister 1984, pp. 94-7).

To understand the 'contract' between Crown and Church, it is important to note that some of the services rendered by it, such as the Bull of the Crusade (the source of tax income that most grew in this period), were not in reality paid from the pockets of the clergy but by the faithful, who were encouraged by the clergy to acquire these Bulls. Moreover, as with the cities, the churchmen did not always offer their resources free of charge. For example, the negotiation over the excusado allowed the ecclesiastical institutions to strengthen or obtain certain economic privileges, principally in relation to the 'sale of cereals without any limitation' (Álvarez 1990, p. 125).

The relationship with the Crown and the image of a common enterprise in defence of the faith increased the Church's spiritual capital and prestige. The country's growing identification with the anti-Protestant and CounterReformation causes enhanced cultural beliefs that were highly positive in respect to the Catholic Church. The result was a flow of donations and charity from the faithful, who saw it as the principal bastion in the defence 
of Christendom. ${ }^{41}$ Thanks to all of this, the entailed properties in the clergy's hands were extended, and overall ecclesiastical incomes increased even more quickly than the Church's contributions to the king. ${ }^{42}$

Philip II has passed into history as a king in constant tension with Rome, a staunch defender of his right of 'presentation' of bishops and indefatigable in his efforts to control the Inquisition. But his relations with the Catholic Church in Spain and America were decisive in allowing this institution to prosper and to continue to be the receptacle of a large number of members of the elites. This fact relaxed the tensions generated among the nobles by their need for social expansion and would be crucial for the social consolidation of the dominant coalition in spite of its internal structural tensions.

In conclusion, absolutism did cut off some of this dominant coalition's opportunities for expansion. But in other ways, it helped and favoured its members by creating channels apt for their forms of social expansion, thus reinforcing a difficult but solid agreement between the Crown and the elites.

This was evident in many different developments. No records have been found of the collapse, extinction, or ruin of a single great seigniorial house during these years. Protected by the mayorazgo, their extraordinary incomes, and access to credit, their patrimonies did not dissolve; at most, they passed to other lineages through political marriages and inheritances. Many secondary branches of these houses satisfied their needs for promotion and increased their power and wealth to the point that they were actually able to complete with the central trunks of these lineages. The case of the Count Duke of Olivares, who belonged to a lateral branch of the Guzmán, is perhaps the most eye-catching example (Chap. 8). But something very similar happened with the house of Sandoval. Beginning at a relatively secondary position, with limited economic resources, this Castilian-Aragonese house not only rode out a number of storms but even became one of the most powerful in Castile by the early seventeenth century through the person of the duke of Lerma, favourite of Philip III. The security offered by the mayorazgo was instrumental to this rise, as was the matrimonial policy that allowed it to form ties with powerful lineages such

\footnotetext{
${ }^{41}$ Sermons on the Bull of Crusade were preached in the hope of encouraging poplar passion for this institution. For ironic comments, see Leonardo Donato's view in García Mercadal (1999, vol. II, 360).

${ }^{42}$ See the example of Madrid in López ed. (1998, pp. 82-7). For a wider vision, Atienza (1988), whose figures are presented in the following chapter below.
} 
as the Gandía; also important was the decisive intervention of members of the ecclesiastical hierarchy-indeed, one such figure, Cristóbal de Sandoval, was illegitimate. The house's capacity for promotion is eloquently demonstrated by the fact that in the early 1600s three of its members possessed the ducal dignity (Williams 2006, pp. 15-30).

Between 1520 and 1631, more than 600 new titles were created, the vast majority being conferred upon individuals drawn from the high nobility, its lower ranks, and the urban elites. Obviously, if these titles represented the avidity of the Crown to satisfy the desire to purchase dignity and to reward service, then this was just the tip of the iceberg in terms of the capacity for social ascent. An understanding of the role and influence of urban oligarchies in this sector can be gleaned from the fact that of the bishops of Castile, more than 50\% came from an urban background-a vastly disproportionate percentage in relation to the overall population. Between $85 \%$ and $90 \%$ were nobles - an indication of the elites' enormous capacity for promotion and ability to overcome problems. ${ }^{43}$ It is not, therefore, surprising that open conflict and factional disputes in cities should have practically disappeared, being replaced by more pacific means of conflict resolution. The resources of the judicial system and matrimony allowed families to overcome tensions by sealing alliances. In Murcia, for example, the conflict between the Sotos and Riquelmes was largely resolved by fear of a total rupture involving allegations of impurity of blood-this was a form of self-enforcement between clashing groups who, in the end, had similar interests (Contreras 1992).

More widely the process by which elites had become involved in the monarchy and empire, and the capacity of both to offer an outlet for their needs for social consolidation and promotion, also contributed to a certain degree of stability in the political system and social order. In this way many of the fifteenth-century phantoms that had led to rebellions and civil strife-here Spain can be profitably compared to other areas of Europe (Chap. 6)-were palliated.

\section{Global Forces and the Mobilization of Resources}

The process described above should be understood in the context of the globalization and the incorporation of the Iberian kingdoms into an enormous imperial system.

\footnotetext{
${ }^{43}$ See the figures provided by Barrio in his various studies (2001 and 2004).
} 


\section{Silver and the Circulation of Elites Within the Empire}

American silver and the inflationary process it fed had a corrosive effect on some seigniorial economies. Moreover, to the extent that it was accompanied by broader changes in mercantile development, it accentuated a number of social imbalances. But it also exerted a stabilizing effect on institutions, an outcome that is often forgotten (Yun 1998).

The quantities of silver arriving from America never constituted more than $25 \%$ of the total income of the Crown (Flynn 1982). This was not, of course, a small proportion. Many European princes could only have dreamed of something similar, especially as this was a source of revenue that was not under the control of the Cortes of Castile. But it is even more important to underline that American silver made possible the use of mechanisms for the conversion and consolidation of debt described above which was the cornerstone of the whole financial system, as well as the series of 'contracts' between the Court and the different factions of the elites. The subjects of Castile paid for a good part of the costs of the imperial system in Europe with their taxes. But it was the forced labour in the American mines and the taxes levied on their silver that made possible the pact between the monarchy and the elites, thus converting Castile into the backbone of the monarchy's imperial complex. Other countries of course underwent similar processes (see Chap. 6), but the arrival of silver marked a fundamental difference in the case of Spain.

Also the policy of the Crown with regard to the Iberian aristocracies was especially effective thanks to the arrival of Indies treasure fleets. The precious white metal facilitated a level of fiscal extraction and a type of involvement of the kingdom in the tax system that meant that the pressures on the nobility remained reasonable. The expansion of the amount of money in circulation was behind a process seldom remarked upon: it meant that nobles could now borrow to perform services requiring their direct mobilization, such as their deployment in the war against the Moriscos of Granada. Had credit not been available, their only means of providing these services would have been through immediately extorting their vassals and tenants or by using very painful lines of credit. Furthermore, the increase of available specie and the security in the repayment of the public debt that it generated help to explain (they were not the only reason) the lowering of interest rates that allowed the Crown to decrease rates charged on both juros and censos, whose weight fell upon the nobility. Without America, not only the stability of the monarchy but 
also the financial steadiness of the aristocracy and the opportunity to apply the credit policy described above would have been very difficult.

American silver was also crucial for the formation of the powerful network of financiers serving the king, something which contributed decisively to the creation of the Habsburg system and the conflictive pacts within it. Captured in America or Seville by the Italian or German families, silver energized their financial circuits in a way that would have been unthinkable in the fifteenth century. ${ }^{44}$ As we have seen, American silver made possible the circuits between asientos and juros upon the royal taxes that characterized the financial system, as well as the mechanisms that allowed Madrid to 'camouflage' the operations for the transfer of funds from Castile to the European theatres of war. American silver was, therefore, crucial to overcome the technical and institutional constrictions of the composite monarchy.

The flow of silver and the expansion of American commerce were also relevant for the consolidation of the urban oligarchies, even if that commerce was smaller than usually thought. Global commerce, with the American trade as its vertebral column, and the growth of the class of merchants tied to it, created tensions in the very heart of the settled society. But these developments had an impact on the expansion of the elites. Though it was not the main factor, the arrival of the migrant's remittances could not but help to alleviate their internal tensions. Official figuressubstantially less than the real total, without doubt-come to $1.3 \%$ of the GDP by 1591-1600. ${ }^{45}$ This is not a huge proportion, but it needs to be remembered that an important part of it fell into the hands of a tiny amount of the overall population. Since part of this amount was made up of payments for exports from the peninsula, it seems logical to think that it also enhanced the conditions for the success of a merchant class that was able to mix with the old families of the urban elite, thus favouring their social and economic reproduction. The impact in Seville is, logically, the most evident phenomenon. Not only merchants-some of them of converso origin-but also a good number of mid-ranking nobles and even some aristocrats dedicated their time to commerce and made headway in this city of blue bloods (Pike 1978). This was often achieved by taking

\footnotetext{
${ }^{44}$ Although the literature on the matter is huge, a useful synthesis can be found in Ruiz Martín (1990a, pp. 16-23).

${ }^{45}$ These estimates are based on Hamilton (1975, p. 47) and Yun (1998, Table 2).
} 
advantage of the noble status enjoyed by certain Genoese families involved, directly or indirectly, in American commerce.

Also highly significant were the opportunities the Empire offered its elites for circulation and promotion in America and Europe. As a result, these dominant groups enjoyed extraordinary geopolitical advantages, an exceptional factor-if we compare them with their European peers, with the possible exception of the Genoese, who constituted one of the epoch's most stable elites, due to the solidity of their pact with the Crown.

An analysis of emigration to the Indies and of the domestic life of the great noble houses might well demonstrate that very few of their members went to live in the New World. Certainly there were very few cases of mixed marriages with the 'indigenous nobility'. ${ }^{46}$ This is logical, given that aristocrats sought to marry reflections of themselves that might not be perceived in American elites. However, from the end of Philip II's reign, many viceroys-perhaps, indeed, all of them-belonged to these great families (Schäfer 2003, vol. II, Appendix I, pp. 381-4). This form of service brought in large sums of money as extraordinary incomes, being one of the most sought-after benefits of the auxilium. Office holding certainly served to soften the so-called crisis of the aristocracy - this was a very mild crisis in Iberia-and to confront the internal aspirations within these families. In turn this affected not only the leading members of lineages but also their collateral branches, many of whose members travelled abroad to serve to their great profit and benefit. There are also a few fascinating cases of Iberian families creating American branches. The Borja-Gandía lineage provides one such example, as does the second branch of the Velasco, who created a whole dynasty in México after D. Luis de Velasco y Ruiz de Alarcón served as viceroy of New Spain. But these cases are surely symptomatic of a broader trend (Redondo and Yun 2008). The part of the aristocracy most affected by this process was, by some margin, the Castilian lineages. Yet a number of families of Valencian origin (such as the BorgiaGandía) were progressively tied to the Castilian clans forging ties in Aragon and even in Italy. In this way the positive effects of the empire were transmitted through these families into and towards an aristocratic elite that was increasingly marked by a transnational component and that was becoming Spanish more than Castilian, Aragonese, and so on (Redondo and Yun 2009).

${ }^{46}$ See the case of Moctezuma's descendants in Hernández Franco (2006). 
Nobles were most commonly employed on the European side of this empire. Forever conscious of the dynastic component and wary of the multiple layers of opposition to foreign elements, the Habsburgs seldom sought to employ subjects from one kingdom in the local administration of another state. However, from the second half of the sixteenth century, many members of noble families came to serve as viceroys or pursued military careers in Europe. Well-known cases such as that of the duke of Alba were not unique or exceptional (Maltby 1983). Careers of this sort allow us to trace family strategies, as in this case not only the 'Iron Duke' himself but all the Álvarez de Toledo lineage became active in the European theatre acquiring offices, promoting second-born sons, discharging military and diplomatic commands, or marrying daughters with prominent families in Italy or elsewhere. ${ }^{47}$ The monarchy of the Habsburgs of Spain required an efficient and stable diplomatic service: by the end of the century, the ambassadorships dotted across Europe were generally in the hands of members of families of this sort (Redondo and Yun 2009). In turn nobles came to assume that this type of office was something like a birthright; on the other hand, this kind of position required an initial burst of expenditure by the office holder, who usually made use of censos to cover this outlay (Yun 2004). Nobles, in other words, were the most logical incumbents of this sort of office.

The employment of the Iberian nobilities in the imperial system further accentuated their ties with other European aristocracies. Families of Aragonese origin (the Riquelmes, the Santa Coloma, the Denia, and others) and Portuguese origin (the Castro and Silva) used these bonds to achieve forms of promotion that relaxed the internal tensions mentioned above and which, in time, changed their very nature and relationships with their places of origin (Redondo and Yun 2008). This transformation offered certain economic advantages and opportunities (noticeably honours and military habits), thus reinforcing both the alliance that connected Castilian nobles to the Crown and the opportunities for promotion of this social group. An analysis of the marriages of the members of the Order of the Golden Fleece between 1575 and 1600 demonstrates that the Castilian families had become the marriage partners of choice for many European nobilities (Yun 2016). This matrimonial market opened up avenues for

\footnotetext{
${ }^{47}$ The clearest case is that of the viceroy Don Pedro de Toledo, whose daughter, Doña Leonor de Toledo, married Cosimo de Medici, duke of Florence (Hernando 1994; Palos 2016). More examples can be found in Redondo and Yun (2009).
} 
promotion and unblocked the internal tensions of these lineages. While the links were weaker with the Flemish houses, an entire chapter might be written on their marriages with the Italian lineages of Roman, Genoese, Sicilian, or Neapolitan origin. These interactions afforded them not only political and social capital but also the economic fluidity that allowed the high and mid-ranking aristocracy to face their domestic difficulties. Genoese marriages were particularly beneficial—and lucrative-in this regard. ${ }^{48}$

This imperial complex stood at the heart of the relationship between the Crown and the elites, in large part because of its capacity to satisfy those elites' needs for social and financial capital. Many members of this social sector assumed military offices and followed careers that offered the chance of social promotion or of avoiding the negative effects of the mayorazgo system. Figures such as Garcilaso de la Vega, Juan Boscán, and many members of the intermediate nobility ended up obtaining habits in the Military Orders (Postigo 1988). The martial professions (fighting and its related logistical and bureaucratic machinery) and the waging of war in America also provided a fertile terrain for these groups (Martínez 1993, vol. I, pp. 118-26), which shortly came to see the New World as a promising area for expansion. The known cases are highly evocative in this regard. These elites served as members of aristocratic retinues, as officers in the royal bureaucracy, or as businessmen who decided to remain in America. These were men drawn from the ranks of the hidalgos, or members of the middle classes in danger of falling into poverty (Martínez 1993, pp. 120-3). Families such as the Espinosa provide an excellent example of how dynasties incorporated merchants, businessmen, clergymen, and nobles, thus establishing transatlantic ties and so taking full advantage of the enormous advantages conferred by the empire (Lohman 1968). This social class provided many of the university students who created the dynasties of functionaries and lawyers who made their living in the New World (Pelorson 1980). ${ }^{49}$ These (often temporary) emigrants not only sent money back to the Iberian Peninsula; those returning from the New World also brought back wealth that also alleviated the internal tensions within this group. Waves of emigration were therefore crucial to the process that, whether it ended in premature death or fabulous fortune, freed the Iberian political theatre of a great deal of pressure.

\footnotetext{
${ }^{48}$ See, for example, the case of Ambrosio de Spinola in Rodríguez Villa (1905) and Herrero (2009).

${ }^{49}$ For detailed studies, see Hampe and Honores (2004).
} 
As it has been said, another important absorbent of the tensions within the Iberian elites and within the whole society was the ecclesial structure in America. Indeed, the expansion of the Church into the New World might be considered one of the most significant consequences of this emergent global empire. The emigration of churchmen, among them many lateral members of noble lineages, to the Indies was perhaps one of the most important means of reducing peninsular tensions. No exact figures can be provided, but it has been estimated that during the sixteenth century, some 6000 clerics crossed the Atlantic; this was a significant number if we remember that a number of them belonged to the tiny middling ranks and oligarchies of this society (Borges 1983). And so, aside from the fortunes involved, America was used to win over the clergy and to ensure the circulation of elites, from whose rank the Church assiduously recruited part of its members (McAlister 1984, pp. 94-7).

\section{Mobilization of Resources and the Limits of the System}

The status quo established between the Crown and the elites served to frustrate profound changes in the central finances. As pointed out before, the process was, of course, very far from a financial revolution of the sort taking place in Holland. But, more important and against an implicit idea very much accepted for years, the outcome, on the other hand, was clearly not a prototype for a centralized fiscal state that would allow the total concentration of military power and social coercion in the hands of an absolute king, as was believed until relatively recently.

In regard to the former, it has to be said that, despite its technical and constitutional sophistication, the Castilian financial system differed from that of Holland after the 1580s and from that of England after $1688 .^{50}$ The key to what happened in these countries was the development of parliamentary systems characterized by a relatively high degree of political representativeness, which gained control over the budget and public debt. In 1688 this system was accompanied by the creation of the Bank of England (in 1694) that would advance money to the treasury and, indeed, would end up controlling the money supply. Logically, this has been considered a key step in the development of institutions that allowed a marked increase in the capacity to sell state debt bonds (North and Weingast 1989). The situation of Castile (let alone the other kingdoms) was very different.

${ }^{50}$ Tracy (1985), 'T Hart et al. (1997), and Brewer (1990). 
It is evident that the Castilian political model was very far from achieving the optimal conditions for a financial revolution. The Cortes suffered from a lack of representativeness, and some scholars have even questioned the ability of the city and town councils to control their own representatives in the assembly (Thompson 1989). The Cortes could rail against the costs of war and the transfer of money from the kingdom but had no control over expenditures. On the other hand, the development of the American-Genoese axis (mentioned above) placed the function that central banks would later perform (the management of debt) in the hands of an international corporation, which did not seek to benefit the kingdom but only to secure its own private interest. Here it is worthwhile remembering that in reality the Bank of England emerged as an institution offering annuities to subscribers, something that set it very much apart from the corporation of bankers who advanced shortterm loans at high rates of interest to the King of Spain. ${ }^{51}$ Behind this there stood the fact that the conflictive pact with the Crown was leading to a situation in which neither of the twin fiscal and financial poles of the monarchy-the cities and the Genoese-wanted to introduce substantial changes unless it was clearly in their interest to do so. And their interests were the opposite (Ruiz Martín 1990b). They therefore created a sort of paralysing equilibrium. This was for a variety of reasons and despite the fact that the Crown sought to take advantage of any dispute between them.

Quite a few of the Crown's efforts to reform the financial fiscal machinery sought to give it the very thing it most urgently lacked: a banking system that would allow cheaper credit and, as a result, the replacement of the Genoese. The project to convert the House of Trade (Casa de la Contratación) of Seville into 'a commercial bank and, at the same time, a deposit bank for the public debt of the Spanish Monarchy' is one of the most significant of these efforts (Ruiz Martín 1965). This scheme sought to attract private savings, some of them tied to the American trade, and so reduce both the high interest rates charged in the asientos and the role of the Genoese. The same might be said of the project of Valle de la Cerda and Oudegherste. Inspired by developments in Holland, which now stood on the brink of a genuine

${ }^{51}$ See the synthesis on the Bank of England of Van der Wee et al. (1991, pp. 246-53). 
financial revolution, the intention was to create a network of local public banks. The idea was to attract savings by the granting of censos and the negotiation over juros: deposits obtained in this way would be advanced as loans to the king, thus displacing the hated Genoese (Dubet 2003).

Problems were compounded by the fact that this fiscal system lacked a genuine central treasury that would have permitted officials to make a precise estimate of its possibilities. Moreover, the behaviour described above (the management of the debt through asientos based upon incomes which were more or less known and secure) was just one part of the system. Many juros were sold directly by the Crown officials, and many investors and businessmen had to accept juros as compensation for seized Indies cargoes or Crown bankruptcies. Nothing could be imagined further from a system of debt based only upon the confidence of subscribers guaranteed by the control of the budget by the parliament.

What emerged in Castile-and in the other kingdoms under the Habsburgs - was very far from the model of a unified fiscal system that might serve as the basis of a centralized military state.

There was (for the epoch) a quite evolved royal fiscal and financial system, which was the pillar of the important development of military technologies (Parker 1972). Thanks to the former, thousands of soldiers-most of them mercenaries and not Castilians (Ribot 2008)-were paid in Flanders, Milan, and other areas of the composite monarchy. Even the American incomes were more and more used to pay for the different bodies of the navy there. But due to financial and logistic problems, theses armies were often decentralized in their logistic support, and contractors and asentistas played a very important role to the extent that it has been possible to identify a 'decentralization' that shifted the management of the army from the central government to the periphery and from the public administration to the private one (Thompson 1976: conclusions). It is not odd that some historians have recalled that the empire's bureaucracy in fact involved of a very tiny group of people (see, e.g. Stradling 1981: General Introduction).

Furthermore, the relation of tense cooperation that had emerged between the Crown and the elites also had a dimension outside of the fiscal system, one which is important for the understanding of the specific (and relatively limited) role of public finances in the mobilization of resources. The auxilium of nobles and aristocrats fed military and bureaucratic systems that had emerged in the Middle Ages and had a marked private and decentralized character. This involved direct military action by 
nobles or aristocrats who, having usually obtained financing through censos and credits, carried out missions on behalf of the Crown. This was a common occurrence in frontier areas like Murcia, where the military function of nobles such as the Marquises of los Vélez had been maintained during the fifteenth century (Owens 1980). This is just one case among many. The various forms of noble mobilization (cited above) maintained the military role of the aristocracy. This was especially commonplace in those regions which had close links with areas directly involved in military conflict of one sort or another and would become even more usual in the seventeenth century. Of course, the nobility was not the only active participant in practices of this sort. The cities, in reality collective seigniorial estates that are, therefore, also obliged to auxilium and military service, performed a very similar function. Seville, Granada, Valencia, La Coruña, Murcia, Cartagena, and many others found themselves compelled to carry out levies of soldiers and to maintain high levels of direct spending and/ or to assume debts for defence purposes. ${ }^{52}$

This picture should not surprise us, even though it breaks with the traditional and overly simplistic view of centralized fiscal systems of military mobilization. Recent research on other countries has also shown the importance of military entrepreneurs and private armies and mobilizations (though in Spain this was not strictly the case, since the señorios of nobles or cities cannot be considered to be private) (Parrott 2012). Perhaps these private operations, for all that they attract the attention of specialists, have been viewed as less significant in the overall tapestry. It is to be noted that these methods and mechanisms, although widely divergent in themselves, bear many similarities to those employed in the conquest of the Americas (Chap. 2). They were based on a codex of auxilium and an ethos of personal initiative in exchange for the promise of later compensation.

It is impossible, for the moment at least, to calculate the economic value of these mobilizations and the debts they generated. Perhaps their overall significance was slight in quantitative terms. But we know, for example, that during the years 1589-1593, the censos subscribed by nobles to cover services

\footnotetext{
${ }^{52}$ Thompson (1976, pp. 11-37). The Morisco rebellion was largely fought with local levies and contributions from the cities of the south and eastern regions of the country. Seville paid 61,000 ducats (p. 18). Valencia came to pay 50,000, and cities in Catalonia, Sardinia, and Mallorca had to do the same on a number of occasions (pp. 19, 23). The same happened on the Cantabrian coast, which contributed 60,000 ducats 'with no cost to the royal patrimony' (p. 24).
} 
(principally military) to the Crown rose to 1.6 million ducats, which represented $18 \%$ of the income collected in asientos in these years. ${ }^{53}$ And it seems probable that the cities made military contributions and efforts of a similar or greater scale. Though maybe exaggerated, the case of Seville is very meaningful. To give an idea, the principal of the censos imposed upon the city's budget by 1595 was about 1.1 million ducats, which, extrapolating to the whole kingdom of Castile, would mean the equivalent of the juros' principal at the end of the century. Even taking into account that this is (probably) too high a figure and that more than half of it was the result of municipal expenses, it represents a large amount that cannot be forgotten in any study of the debt of the composite monarchy. ${ }^{54}$

Mobilizations of this sort worked within the existing fiscal arrangements and demonstrated the reality of conflictive cooperation: they served as one of the pillars of the political and social agreement between elites and the Crown. They would have a significant impact on the political economy of the empire and the process of state building. From the viewpoint of fiscal affairs, taxes were generated as a cascade: many of the fiscal impositions of the Crown upon the towns were paid by them by advancing to the king money which they obtained thanks to the subscription of censos on their municipal finances. And this was also the case for the payment of the local militias: to finance them the municipalities asked the king for permission to take censos and to create new taxes to make interest payments. Thus noble and town debts are important, and any definition of the 'public debt of Castile' needs to include not only the juros - that is the royal debt - but also the censos created for the accomplishment of the public tasks and functions (military commitments included) that these arms of the state were obliged to carry out. ${ }^{55}$

\footnotetext{
${ }^{53}$ According to my calculations, the average annual figures in ducats for various periods and years are 43,000 (1565-1569); 5400 (1574-1578); 77,500 (1579-1583); 25,000 (1584-1588); 330,000 (1589-1593); and 96,000 (1594-1598). Cámara de Castilla, Libros de Relación, libs. 14, 18, 21, 25 y 26, AGS. The calculation must be taken with some precautions. Probably, the nobles spent important quantities without previously asking for either a censo or a mortgage on their mayorazgos. And, in another sense, not all costs derived from war spending.

${ }^{54}$ See the figures in Martínez Ruiz (1992). I have extrapolated this onto the entire kingdom by taking into account the population of Castile.

${ }^{55}$ See these mechanisms in Ruiz Martín (1994) and in my 'Introduction' to Ruiz de Celada's book (Yun 1990).
} 
The machinery for the mobilization of resources was, therefore, more far-reaching than has sometimes been supposed. The same could be said about its debts. It is quite possible that, taking all the contributions and exactions into account, recent optimistic estimates on the weight of taxes and the sustainability of the debt may have to be revised. As we shall see, this is also crucial to understand the state-building process.

One result of all of this was that military administration came to be characterized by a high degree of decentralization resulting in relatively poor performance and fraud. This would proceed to the extent that it resulted in what I. A. A. Thompson called the 'devolution of functions', in which military administration and even the conduct of war were placed in private hands. As a whole this system created a complicated and conflictive machinery, whose deployment was made more costly by its very character and which was permanently marked by clientelism, patronage, nepotism, misadministration, fraud, and corruption. This would be as much the case in Flanders as in Castile itself, and it was equally evident in the relationships between the various theatres of action and the functioning of the fiscal and financial system that fed the logistical apparatus. ${ }^{56}$ Similar patterns were, of course, frequently found in other territories of the monarchy. The contracts for the maintenance of galleys in Genoa (especially those signed with Andrea Doria) provide a good example; again, arrangements of this sort would become more common from 1600 (see Chap. 8) (Williams 2014). In regard to the military system as a whole, it has been said that the 'centralisation of the Spanish administration was purely personal. In the same way that the monarchy was the sum of autonomous and privileged nations, united only by their loyalty to the same sovereign, the internal constitution of Castile was a conglomeration of liberties and independent jurisdictions centralised in the person of the king' (Thompson 1976, p. 42). Moreover, the Council of War was a 'Cretan labyrinth' and highly ineffective. Controlled by the aristocracy until the reforms of the end of the century, it was engaged in continuous rivalries with other councils. It exercised judicial responsibilities that weakened its capacity for quick responses and never managed to secure a monopoly over the control of military affairs.

All of these failures had their origins in 'profoundly structural weaknesses'. As in all monarchies of the time, at its heart lay a system of patronage for the conferment of offices and loyalties, one entirely consistent with

\footnotetext{
${ }^{56}$ For these territories, see Parker (1979) and Thompson (1976).
} 
the principle of do ut des. Patronage did not, to be certain, necessarily involve the king (it was often a relationship between nobles involved in war and their subjects) or function according to the idea of office as a source of benefit typical of the period. As a result, the working of the administrative system was clumsy and costly to maintain, functioning according to a series of highly complex codes in regard to what today would be considered corruption (Yun 1994a). Furthermore, local authorities played a vital role in the collection of monies destined for war. For this reason much of the royal revenue ended up being lost on the wayside. ${ }^{57}$ Finally, the mobilization system did not serve exclusively military ends, in part because of its institutional and social limitations. It was also used to feed the machinery of distribution of resources that came to be set out in the situados and libranzas claimed by nobles, patricians, and ecclesiastics, who absorbed the royal taxes at their very point of collection, thus reducing the remittances to the king. The result, again, was to broaden the disparity between the theoretical funds and the actual amounts. ${ }^{58}$

\section{The Empire As a Solution in Portugal}

Overseas expansion provoked important social tensions but also served to stabilize Portuguese society.

If a sizeable number of the merchants and financiers were of Italian origin (specifically Genoese), the Portuguese group (especially New Christians) was also notable. It became even more so following the expulsion of the Jews from the Crowns of Castile and Aragon in 1492. As in the rest of the peninsula, this was the origin of considerable tension that was manifested as a rejection of religious beliefs but which betrayed an ever more pronounced ethnic element. In some way these tensions were an Iberian materialization of the more general clash between nobility and

\footnotetext{
${ }^{57}$ As is well known, this is not a trait exclusive to Castile or to Iberian financial systems in general. See Collins (1988).

${ }^{58}$ In 1572, the Venetian ambassador Leonardo Donato estimated the income of the King of Spain as some 5.6 million escudos but believed that debt interest repayments absorbed 2.2 million and 'ordinary spending' (including the situados and running costs) 2 million. 1.4 million was, therefore, the net available sum: this was, very probably, highly optimistic. He believed that the situation was even worse in the Low Countries, where 'nothing comes out clean', L. Donato, 'Relación de España' (1573), in García Mercadal (1999, quoted on pp. 362, 386).
} 
businessmen. But commercial development and economic growth also fed pressure for the social advancement of the urban oligarchies and merchants, which increased tensions within these elites. As in the other Iberian kingdoms, the nobility was compelled to increase military costs on the peninsula-less so, perhaps, than in Castile-as much as in the colonies (VilaSanta 2015, pp. 71, 77, 85, 94, 113-5). And the development of royal justice clashed with the expansion of the jurisdiction of the seigniors (Hespanha 1989, pp. 414 and ff.), while a mentality of patronage increased their social obligations and prestige costs (Da Cunha 2003). The Portuguese nobility even came to apply forms of Malthusian self-control that, perhaps because they have passed under the historians' radar, are unknown in the other Iberian kingdoms (Carvalhal 2016, pp. 5-6; Boone 1986). This phenomenon, closely associated with a masculine hierarchy of ever-greater intensity in the houses of fidalgos and an extension of the morgadio, the equivalent of the Spanish mayorazgo (Monteiro 2003), led to the increasing entrance of daughters and second-born sons in the Church, this being a way of reducing internal tensions within the lineages (Boone 1986).

But, as in Castile, the overseas expansion favoured the consolidation and social promotion of elites (the early forms of this development have been described above). A considerable number of fidalgos (many of them belonging to secondary branches in the lineage or second-born sons), mid-ranking nobles, and even traders found that conquest served as a form of social development and gave an outlet to the internal tensions and family aspirations. This fact was manifested in what Magalhães Godinho (1963, pp. 213-4) called the cavaleiro-mercador, a noble dedicated to commerce who, in many senses, can be seen as the updated version of the knight errant of the Middle Ages, who had used foreign wars as an instrument of social promotion. Given the mixing of military violence and commerce-more often than not, extortion-which marked Portuguese actions on coastlines from Morocco to China, the figure of the cavaleiromercador was not necessarily or inherently contradictory (other countries were, of course, equally violent or exploitative). Beyond this oligarchy consisting of the intermediate nobility, some members of the great aristocratic dynasties could also find an outlet for their desire to reproduce their lineage and family through the empire. This was, however, a numerically small group. In fact the offices of governor and viceroy in the Estado da Índia were divided almost entirely between five families (Da Cunha and Monteiro 2005). But the cases are highly significant. The most eye-catching example is that of the governor Alburquerque, but he was followed by a 
considerable number of captains general, governors, and viceroys of the Estado da India, such as the different members of the Telles, Ataíde, or the Sousas Chichorro (Da Cunha 2005; Vila-Santa 2015; Pelúcia 2009). With regard to Brazil, families such as the Alburquerque and the Sá were prominent also in this process (Boxer 1952; Norton 1965; Viana 1968). And, of course, the Church, both secular and regular, offered another means of expansion. If only a few bishoprics were created, the Portuguese orders in general and the Jesuits in particular were able to impose themselves upon both Asia and Brazil, thus becoming a channel for the expansion of the elites. The Crown's right to padroado (similar to that of patronato in Castile) served to satisfy the elites' need for social reproduction and the projection of their clients into an ecclesiastical system that by now was acquiring global dimensions. The Military Orders created the social space fitting for the entrance of members of the nobility and the fidalguia - and even, indeed, for commoners (Olival 2001).

As Subrahmanyam and Thomaz have shown, noble emigration was small in absolute numbers (1991, p. 319). This is logical given the size of the group. But the impact of the empire should not be overlooked. To understand this, a wider perspective has to be adopted. As in the Spanish case, the empire bestowed upon the kings an extra income that allowed them to reduce the pressure of the Crown upon the aristocracy, fidalgos, and merchants, which in turn may have reduced tensions within the dominant elites. At the same time, this income extended the Crown's capacity for patronage towards these groups, not only in the colonies but also in Portugal itself. It is important to note that, from 1555, the Crown obtained from the Pope the titular leadership of the Portuguese Military Orders, something which allowed it to intervene in the conferral of habits and estates and so became a crucial method of ascent within the nobility (Olival 2004). This implied a notable increase in the Crown's capacity to offer patronage to the elites at the same time that it took possession of a fundamental tool for the regulation of the internal tensions of this group. And it should be remembered that this pontifical concession was consistent with the function of the empire-in Africa and India-as a means of propagating the Catholic faith.

This permitted the aristocracy to abstain from a systematic revision of the system of enfiteusis which, having created favourable conditions for the farmers, was one of the pillars of the agrarian growth achieved in the sixteenth century. Any attempt to understand the positive medium-term effect of the colonies must also take into account the broadening of the 
ecclesiastical structures within them. This was another balm that facilitated the consolidation and resilience of elites. A study of the Portuguese ecclesiastical chapter houses has underlined that the situation was very similar to that of Castile: the basis of a genuine church patriciate, they served as spaces for the projection and social development of families belonging to the local oligarchy (da Silva 2013). Portugal, in distinction to France, England, and even the Low Countries, hardly saw any big social conflict in the sixteenth century nor indeed until 1637-1640. This can be explained partly by religious factors but also by economic and social ones and more in particular by its elite's capacity for reproducing themselves.

This dynamic would not be broken in 1581. The annexation of Portugal by the House of Habsburg may have been violent, but it also meant that Portuguese elites could continue with their model of social reproduction. As the historiography of both countries has underlined, the Dutch and English attacks upon Portuguese possessions after 1580 certainly entailed a cost for these elites. But it is also worthwhile remembering that before the union of the Crowns-indeed since the 1540s-expansion in Asia had been slowed and the defence of the empire rendered increasingly difficult. In this light it is not surprising that a large part of these elites saw Philip II (Philip I in Portugal) as a solution to both their problems and those of the empire (Disney 2009, vol. I, Chap. 10). This is especially true when we factor into consideration the indebtedness of some of them as a result of their efforts to follow King Sebastian in his extremely expensive and disastrous African campaign, which ended in his death and that of many of his greatest nobles (Disney 2009, vol. I, p. 179). Many families belonging to the high nobility, whose position can be explained also by their previous links with their Castilian counterparts, henceforth adopted policies that clearly aimed at their mingling not only with their peers from over the border but also with groups from other regions of the monarchy, including Italy (Da Cunha 2009; Redondo and Yun 2009). And this did not entail losing their scope to project themselves on the empire, where viceroyalties were becoming ever more the preserve of the aristocracy, as were the governorships within the Estado da Índia (Da Cunha and Monteiro 2005). The empire was not only a source of offices and royal charity but also of profitable commercial licences granted to many fidalgos and, above all, the Braganza (Boyajian 1993, p. 34). This fact allowed these families to expand their political capital and even their economic potential. As we shall see, the economic upsurge that the Portuguese empire experienced thanks to its connections with the Spanish favoured the circulation of elites throughout this colonial system. 
Even the commercial bourgeoisie and the New Christians, who may not have entertained high hopes for the intolerant fervour of Philip II, came to experience an important advance after 1580 (Boyajian 1983). The creation of titles-accelerated between 1580 and 1640-would be a cause of discontent for some of the old lineages but also an escape valve for the ambitions of others. The augmentation of the ecclesiastical institutions was continued, while Philip II further strengthened the growth of the Society of Jesus, known for its capacity to recruit young fidalgos and aristocrats from both kingdoms (Lockhart and Schwartz 1983).

The Crown's increased scope for patronage also reinforced these trends. As in the other Iberian kingdoms, the king's power of arbitration was strengthened. In Castile this process reinforced the dedication of resources to what has been called the economy of legitimation, which in turn contributed to social stability (Chap. 6). This was fed from the private accounts of the elites. But, above all, it was given a more visible expression through the development of the Misericórdias. While similar to confraternities and institutions providing social security in other areas of Europe, these represented a more advanced model. They were institutions that, depending upon the king, brought together initiatives aimed at fostering solidarity between their members, such as charity and alms to the poor (Bethencourt 2009; Sá 1997). Thus empire-and the union of the Crowns-had exerted the same effect as on the Castilian elites. Certainly, the court and the metropolitan administration were, more than the colonies, the most important spaces for social promotion (Da Cunha 2009). But this phenomenon was, at the same time, also the consequence of the growing revenues of the king, which mostly came from the colonies. In this way, the empire was a significant safety valve to advance and favour the consolidation and development of elites, while the king increased his scope for patronage: in this way a dominant coalition was reinforced, in which the role of the king was fundamental.

The Portuguese fiscal organization, which brought balance to the dominant coalition, also supported the reproduction of the social system. A form of tax state (Schumpeter 1955) emerged which was broadly similar to that of Castile but in which the majority of the king's income originated in his dominions and in the imperial monopoly over the trade of the most important products, as well as in the toll revenues. As in Castile, the fluctuations in expenditure had compelled the Portuguese Crown to search for a secure and reliable income (even though Lisbon was not saddled with the enormous debts of Madrid), and the sisas were used as the 
alcabalas encabezadas in Castile-as a fixed and more or less predictable income useful to endorse long-term public debt (Hespanha 1993a). Thus the Portuguese system also worked as a means of creating stable and predictable revenues upon which floating debts could be consolidated, crucial for dealing with fluctuations in receipts. The consequence was an increase in the sisas - or taxes upon the sale of products - administered by the town halls (câmaras), which enhanced the urban oligarchies' fiscal protagonism. Thus in Portugal, as in Castile, it has become common to talk of a devolution of functions referred to as neomunicipalismo in relation to the increasing relevance of the cities, whose role and responsibilities grew from the 1550s (Magalhães 1997). It is possible that, as in Castile, what was occurring in Portugal was a strengthening of an institutional role that had never truly been lost rather than an outright devolution of responsibilities. In any event, all of this allowed for a notable increase in the royal income during the sixteenth century, with a peak being reached at the end of it (Hespanha 1989, pp. 110-1). It also allowed for a non-written pact between the Crown and the urban oligarchies, which strengthened their political and fiscal influence within the towns.

A similar deal was also evident in the more general governance of the kingdom. In parallel, and despite the better organization of the central finances, government was and remained based upon the Consejos (Councils), central institutions that defended not only the rights of the king but also those of the kingdom, thus preserving a high degree of decentralization and agreement at the same time (Hespanha 1989). Thanks to the Ley Mental (1434), the tense pact between king and kingdom represented in the Cortes was accompanied by a greater resistance to the nobles' efforts to usurp the Crown's patrimony without eliminating each other's privileges and spheres of power. At the same time, thanks to the growing power of the corregidores and royal judges, the king's justice was strengthened. But it should be stressed that private jurisdictions were not eliminated (Magalhães 1997). Thus, in spite of increasing absolutism, the king and the kingdom were able to find a point of agreement.

But the differences with Castile were also important. Most of them could be found in questions of proportion and political structure. Income from the King of Portugal's imperial monopoly ranged from $60 \%$ to $68 \%$ in 1520 (Godinho 1968), a quantity that bears no relation to the $25 \%$ that the American treasures constituted in their peak years to the incomes of the Crown of Castile. The second most important contributor to royal incomes came from the import tolls, and to a large extent, these were tied 
to foreign commerce. In this way the sisas constituted a proportionally smaller part, and, consequently, the Crown's financial dependence upon local elites was proportionally lessened. The tax state, defined by J. Schumpeter as one involving a high degree of fiscal involvement of the kingdom in the state income, was less developed in Portugal than in Castile, while its component of rentier state (a state financed by other territories) was far greater than was the case in Castile (Yun 2012). Moreover, in contrast to what would occur in Habsburg territories, the Avis dynasty ruled only in Portugal and tensions over the use of resources to benefit other dynastic territories were almost non-existent. Another difference lay in patterns of borrowing. In Castile debts had been generated not only by the disparity between incomes and expenditure but also by the need to pay for distant campaigns that required that funds be sent in advance. Furthermore, the much-praised realism of the Portuguese monarchs, who did not hesitate to abandon their interests in North Africa in the midcentury (Dom Sebastião's disastrous expedition of 1578 being the only exception to this rule), did the rest. Debt never came to exert as much pressure in Portugal as in Castile, thus avoiding many problems. Money was not devalued, nor was there any need to declare bankruptcy, if we except the suspension of payments in 1560, which can hardly be considered as such (Godinho 1982-1987, vol. IV, pp. 215-6).

\section{Peninsular Trends}

Some time ago historians such as, first, H. Hauser and then F. Braudel and I. Wallerstein described the years after the breakdown of 1558 as a period of European-wide crisis and transformation. In light of Castile's financial problems, and those of Portugal in Asia, this idea appears to be corroborated. ${ }^{59}$ These difficulties affected exterior commerce, whose crisis was deepened by the Dutch Revolt (1566) that destabilized Castilian connections with the north of Europe as much as those of the Portuguese markets and financiers (Phillips 1990; Boyajian 1983). During these years Seville's commerce also suffered, and the crisis of the fairs system and of Burgos trade began (Lorenzo 1979, vol. I, p. 199; Basas 1994).

${ }^{59}$ Of the 15 times that Indies cargoes were seized by the monarchy during the century $(1523,1535,1538,1545,1553,1555,1556,1557,1558,1566,1577,1583,1587,1590$, y 1596), five were in the 1550 s, and these unblocked the financial crisis of 1556-1558 (Carande 1987, vol. III, pp. 353-469). 
The domestic economy would also go through problems. Efforts have been made to reduce the importance of the bankruptcies of this periodthese were, of course, negotiated, like all of them (Lovett 1980)-but all indicators lead us to think that the effects on the financial economy were negative in the short term: they produced a breakdown in the credits chain, contributing to immobilize capital, and even affected certain industries. ${ }^{60}$ Even admitting a reduced level of debt in relation to the GDP of Castile-our doubts on this matter have been set out above-the effects of the crisis should be measured in regard to the size of the monetized section of domestic wealth, which was a fraction of the GDP.

The financial problems coincided with a challenging situation in some regions. Since the 1560 s the symptoms of a slowing down of agrarian and demographic growth had been perceptible in some regions of Castile, and in the Duero Valley in particular (Yun 2004, pp. 417-28), while agrarian growth in Portugal also tended to slow down (Miranda 2017). Though, as was the case of Castile (see below), tax pressure was not great in macroeconomic terms, the type of taxes created in this period, and particularly the sisas levied on basic goods, would also have negative effects on artisans' workshops $\left(2004\right.$, p. 344). ${ }^{61}$

${ }^{60}$ As Drelichman and Voth (2014) say, there are good reasons for it. The argument is that in all cases they led to renegotiations of debt or compensation paid by the monarch, measures which, in truth, have been known about for much time. Still there are reasons to think that the effects on the financial economy were not negligible. Not only did these measures create uncertainty, but they also could have been a negative factor for transaction costs. They also delayed the payments made at fairs at precisely the moment when these gatherings had become more dependent upon the injection of money by the Crown at Medina del Campo (Abed Al-Hussein 1982, Appendix 2). See also Carande (1987, vol. I, pp. 325-6, 329-40). Precisely because the Genoese had constructed a cascade system that absorbed the negative effects of the monarchy's failure to make payment (Drelichman and Voth 2014, pp. 160-6), when they themselves were affected, it was difficult for them to satisfy their creditors on time, and these, in turn, found themselves in a similarly dire situation. This extended the effects throughout all productive branches and even hit the owners of juros (for more detail based on primary sources, see Yun $(2004$, p. 338)).

${ }^{61}$ Though some researchers have attributed to us a too strong emphasis on taxes as a factor for Castilian decay, we already gave a very nuanced opinion on this in Yun (1990).

Recently scholars have even come to speak of a variant of the 'Dutch disease' (Drelichman 2005): a greater rise in price of the most commercialized goods, which would have made them less competitive in relation to foreign imports. Here, however, comparisons remain to be fully demonstrated, as wheat can hardly be considered as some of the more commercialized products as Drelichman does (Table, p. 359). It would be more important to consider 
This having been said, the difficulties, if considerable, did not bring about an immediate change in the course of the economy. For at least 20 years (until 1580 or so), most of the regional economies of Castile and Portugal continued to grow thanks to a series of readjustments in the agrarian sector, as well as thanks to the positive medium-term effects of the process of globalization.

In Seville the beginning of a second Atlantic cycle in the 1570s led to an unprecedented period of growth, in part as a result of commercial diversification. This growth occurred as Portuguese trade with Asia was recovering, the trade with Brazil was enhancing the economy of towns such as Porto, and its commerce with the North was reconstructed (Boyajian 1983; Phillips 1990). Sevillian imports of products such as dyes, leathers, and pearls rose quickly (Lorenzo 1979). In turn the emergence in America of markets for Castilian commodities and the development of mines facilitated the exportation of industrial goods. Nor did the crisis of the payment fairs lead to a commercial recession in Castile, thanks in part to the increasing connections with Portugal and Seville (Yun 1987). At the same time, the development of Seville was happening while the financial axis was being shifted from the Castilian fairs towards Madrid (Ruiz Martín 1990a). The growth of Seville and Madrid partially compensated for the problems of the Duero Valley's fairs.

Similar trends were found in the agrarian sector and demographic evolution. The interruption of population growth and agricultural expansion in the Duero Valley and in the interior of Aragon was compensated for by the continuation of the expansive movement in the regions of the South. The model of growth continued to function, being based on demographic expansion and the colonization of southern regions as well as a high degree of connectivity. ${ }^{62}$ At this point the structures and urban networks of Castile remained relatively solid. As a consequence, the problems raised by demographic pressure and the increase of land rent were mitigated by the peasants' capacity to maintain strong links with urban markets and to recur to

that the rise in wheat prices and other primary goods implied an increase in costs relative to maintenance of workshops, thus limiting their competitiveness in relation to foreign goods. But since Vilar's called attention on it, this has been a frequently repeated argument that has slowly taken different meaning (Vilar 1974). This can be seen in a comparison of prices of goods, like wheat, and those of fabrics, for example (Yun 2004, p. 464, Graph 7.6).

${ }^{62}$ This appears to be demonstrated by the figures on urban and agrarian population (Yun 2004, Chap. 4). It is also shown by French emigration into Catalonia which contributed to the population growth at the end of the century (Nadal and Giralt 1960; Durán 1998, pp. 128-31). The population of Valencia continued to increase (Casey 1983, p. 62). 
auxiliary activities associated with commerce (transport services, the production of coarse cloth and crockery, leather goods). All of this was facilitated by the continued abundance of common lands (the selling off of which would be moderate until the 1580s). The farming of intensive crops (such as the vine, silkworm, hemp, and linen), nearly always undertaken in small holdings, was also positive, above all when production was geared towards the market. Nor did the great estates and farms in the South, which benefited from the lowering of real wages paid in cash, collapse overnight. Some areas of Andalusia saw an expansion of olive oil exports to America, while the Catalan nobles invested in iron production, and the Valencian landowners splurged on sugar mills and silk production. ${ }^{63}$

The rise of agrarian prices and of land rents increased the elite's income and their demand for urban products. The overcoming of the elite's economic and social problems thanks to the empire enhanced their consumption of luxury goods. In many towns, the building sector (the construction of palaces in general and ecclesiastic buildings in particular) seems to have increased. The growth during this period of industries such as the textile sector of Segovia was closely tied to the production of high-quality goods consumed by well-off groups, now including the American elites. Moreover, an important feature of this activity was based on the use of raw materials whose prices increased very slowly. ${ }^{64}$ In Catalonia the reorientation of the textile industry was even more intense and decisive from the $1550 \mathrm{~s}$, when a tendency towards a more efficient cycle of agrarian-urban interaction was established. A similar dynamism was exhibited by the silk industry in Murcia, Toledo, or Córdoba, these latter two being noticeable for their progress in adapting to the changing whims of fashion and demand. ${ }^{65}$

The figures and geography for the arrival of American silver, as well as of the types of merchandise purchased with it in 1570-1571, demonstrate that the colonial market was now positively affecting some industries. ${ }^{66}$ Sectors such as naval construction and related industries (wood felling)

\footnotetext{
${ }^{63}$ Pérez and Lemeunier (1984), Jover (1997), Herrera (1980), Fortea (1981), Halperin (1980).

${ }^{64}$ On wool prices, Brumont (1984b) and Pereira (1991, pp. 229-30). The same happened with dyes, like cochineal until the 1580s (Yun 2004, p. 428, Graph 7.5).

${ }^{65}$ García Espuche (1998), Montemayor (1996, pp. 223-8), Fortea (1981, p. 327), Pérez Picazo y Lemeunier (1984).

${ }^{66} \mathrm{Da}$ Silva (1967, pp. 65-101). On the presence of manufactured goods in the American cargos, see (Lorenzo 1979).
} 
were favoured by the growing demand, above all in Vizcaya, Lisbon, Seville, and Porto. The spending of the monarchy clearly contributed to this trend as it built a fleet to meet the extravagant demands of its international strategy. In Catalonia this led to the development of a fleet of smaller vessels serving the Mediterranean ports, a change that demonstrates the relative vitality of the principality's economy ${ }^{67}$

That the two imperial systems were factors for stability in the Iberian societies is accepted by most historians. Moreover, from a very teleological perspective of state building, it has been taken for granted that that process was accompanied by the formation of more centralized tax systems associated with the military revolution. In other words, it has been supposed that the so-called tax state and military state had to be coincident and convergent phenomena.

We have shown here that the empires and, more in particular, the process of globalization were not only factors of stability. In many ways, they were eroding the social fabrics of both Castilian and Portuguese societies and indirectly affecting the other territories. From that perspective the way the empires created political and social stability looks a bit different, and we need to explain why the stabilizing forces prevailed.

Political and social stability and, therefore, the consolidation and slow transformation of the institutional frameworks were the outcomes of mechanisms linked to the way the new fiscal system was organized (above all in Castile) and the way new opportunities in the credit market were used, the opportunities that the empires gave to elites to satisfy their need for expansion and, all in all, for reformulation of the 'contract' they had among themselves and with the Crown. Of course that contract was different in the monarchy's different spaces. By focusing on the case of Spain, we can see that, though contrary to a commonplace, the contribution of other kingdoms (viz. Naples and the Low Countries) increased, the development of a new fiscal system in Castile created a sort of umbrella that allowed other parts of the composite monarchy to preserve their fiscal systems almost intact. Portugal, not being a spread-out composite monarchy, was slightly different.

\footnotetext{
${ }^{67}$ Goodman (1997) and García Espuche (1998).
} 
But this perspective of analysis also explains (better than previous approaches, I hope) that the outcome of these tensions in Castile was not a 'centralized' tax state. The reformulation of the agreement between the Crown and the elites, as well as among those elites, paved the way for a consolidation-not without evolution-of the old institutions. It also contributed to enhance a decentralized system of mobilization of resources for war of which the outcome was the elite's great capacity for exercising coercion, control of violence, and capability of enforcement. Though it is possible that in economic terms the size of the central tax state's budget was higher than that of all of the other corporations combined, the effects from the perspective of the political economy and on state building would be noticeable in all the territories of the composite monarchy. We will return to this.

Open Access This chapter is licensed under the terms of the Creative Commons Attribution 4.0 International License (http://creativecommons.org/licenses/ by $/ 4.0 /$ ), which permits use, sharing, adaptation, distribution and reproduction in any medium or format, as long as you give appropriate credit to the original author(s) and the source, provide a link to the Creative Commons licence and indicate if changes were made.

The images or other third party material in this chapter are included in the chapter's Creative Commons licence, unless indicated otherwise in a credit line to the material. If material is not included in the chapter's Creative Commons licence and your intended use is not permitted by statutory regulation or exceeds the permitted use, you will need to obtain permission directly from the copyright holder.

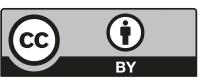

